\title{
Carbon storage versus albedo change: radiative forcing of forest expansion in temperate mountainous regions of Switzerland
}

\author{
J. Schwaab ${ }^{1,5}$, M. Bavay ${ }^{1}$, E. Davin ${ }^{4}$, F. Hagedorn ${ }^{2}$, F. Hüsler ${ }^{3}$, M. Lehning ${ }^{1,6}$, M. Schneebeli ${ }^{1}$, E. Thürig ${ }^{2}$, and P. Bebi ${ }^{1}$ \\ ${ }^{1}$ WSL - Institute for Snow and Avalanche Research SLF, 7260 Davos, Switzerland \\ ${ }^{2}$ Swiss Federal Institute for Forest, Snow and Landscape Research WSL, 8903 Birmensdorf, Switzerland \\ ${ }^{3}$ Institute of Geography and Oeschger Center for Climate Change Research, University of Bern, 3012 Bern, Switzerland \\ ${ }^{4}$ Institute for Atmospheric and Climate Sciences, ETH Zürich, 8092 Zürich, Switzerland \\ ${ }^{5}$ Institute for Spatial and Landscape Planning, ETH Zürich, 8093 Zürich, Switzerland \\ ${ }^{6}$ CRYOS, School of Architecture, Civil and Environmental Engineering, EPFL, 1015 Lausanne, Switzerland
}

Correspondence to: J. Schwaab (jonasschwaab@ethz.ch)

Received: 27 May 2014 - Published in Biogeosciences Discuss.: 30 June 2014

Revised: 11 November 2014 - Accepted: 1 December 2014 - Published: 27 January 2015

\begin{abstract}
In this study, we assess the climate mitigation potential from afforestation in a mountainous snow-rich region (Switzerland) with strongly varying environmental conditions. Using radiative forcing calculations, we quantify both the carbon sequestration potential and the effect of albedo change at high resolution. We calculate the albedo radiative forcing based on remotely sensed data sets of albedo, global radiation and snow cover. Carbon sequestration is estimated from changes in carbon stocks based on national inventories. We first estimate the spatial pattern of radiative forcing (RF) across Switzerland assuming homogeneous transitions from open land to forest. This highlights where forest expansion still exhibits climatic benefits when including the radiative forcing of albedo change. Second, given that forest expansion is currently the dominant land-use change process in the Swiss Alps, we calculate the radiative forcing that occurred between 1985 and 1997. Our results show that the net RF of forest expansion ranges from $-24 \mathrm{~W} \mathrm{~m}^{-2}$ at low elevations of the northern Prealps to $2 \mathrm{~W} \mathrm{~m}^{-2}$ at high elevations of the Central Alps. The albedo RF increases with increasing altitude, which offsets the $\mathrm{CO}_{2} \mathrm{RF}$ at high elevations with long snow-covered periods, high global radiation and low carbon sequestration. Albedo RF is particularly relevant during transitions from open land to open forest but not in later stages of forest development. Between 1985 and 1997, when overall forest expansion in Switzerland was approximately $4 \%$, the albedo RF offset the $\mathrm{CO}_{2} \mathrm{RF}$ by an average of $40 \%$. We conclude that the albedo RF should be considered at an appro-
\end{abstract}

priately high resolution when estimating the climatic effect of forestation in temperate mountainous regions.

\section{Introduction}

The United Nations Framework Convention on Climate Change (UNFCC) declared in the Kyoto Protocol (Decision 11/CP.7) that changes in the carbon stocks of ecosystems, induced by LULUCF (land use, land-use change and forestry) activities can be included in the greenhouse gas emission budget of the signatory nations (UNFCC, 2001). Beside biogeochemical processes, LULUCF also influences biogeophysical processes (Betts, 2011; Bonan, 2008), but these effects are not yet considered in current climate policies.

Global climate models suggest that biogeochemical and biogeophysical effects vary greatly with latitude (Schaeffer et al., 2006; Bala et al., 2007; Bathiany et al., 2010; Davin and de Noblet-Ducoudre, 2010; Arora and Montenegro, 2011). In the tropics, biogeochemical and biogeophysical effects tend to act in the same direction, since tropical forests cool climate through both evaporative cooling and carbon sequestration (Costa and Foley, 2000; Gibbard et al., 2005). However, at middle and high latitudes, biogeophysical processes tend to counter the biogeochemical effect (Gibbard et al., 2005; Betts, 2000; Govindasamy et al., 2001), thus making the net LULUCF effect more challenging to assess. 
Indeed, forestation in boreal regions lowers the albedo and thus counterbalances the cooling effect of carbon storage.

Global climate models are important for understanding the climatic processes related to LULUCF and for quantifying the impacts on climate of forestation or deforestation over large areas. However, in highly heterogeneous landscapes, such as mid-latitude mountain ranges, global climate models are limited by their relatively coarse resolution, and the concept of radiative forcing (RF) (Myhre et al., 2013) can provide a useful alternative. The RF concept has already been employed to investigate the balance between biogeophysical (mainly albedo) and biogeochemical effects following forestation or deforestation. While some studies suggest that albedo RF can completely offset $\mathrm{CO}_{2} \mathrm{RF}$ (Betts, 2000; Bernier et al., 2011; de Wit et al., 2013), others have found that the offset is rather small (e.g. Montenegro et al., 2009; Kirschbaum et al., 2011). The offset seems to vary widely depending on the regional characteristics of the determining variables: global radiation, snow cover, albedo change and carbon sequestration. These factors vary greatly, but little research has focused on how each of them influences RF (Kirschbaum et al., 2011), and only a few attempts have been made to quantify RF in a spatially explicit way (e.g. Betts, 2000; Montenegro et al., 2009). Betts (2000) estimated spatially explicit RF data on a resolution of $3.75^{\circ}$ longitude by $2.5^{\circ}$ latitude. Montenegro et al. (2009) performed their analysis on a resolution of 5 to $25 \mathrm{~km}$. However, RF varies on much smaller scales. Moreover, decisions in regional planning are usually based on very local and regional information; therefore, it is crucial to quantify RF at finer resolutions.

Forest cover has increased in many temperate mountainous regions (Alewell and Bebi, 2011; MacDonald et al., 2000; Ramankutty et al., 2010; Kozak, 2003; Hagedorn et al., 2014) and analysis of LULUCF change in the Alps suggests that changes in forest cover near the treeline will further increase (Gehrig-Fasel et al., 2007). Some of the effects of this increase on various ecosystem services are already relatively well known (MacDonald et al., 2000; Laiolo et al., 2004; Bolliger et al., 2008) and have increasingly been considered in management strategies and subsidizing systems for agriculture and forestry (e.g. Gret-Regamey et al., 2013). However, few attempts to quantify RF in such regions have been made, even though snow cover and hence albedo in temperate mountains varies greatly. To optimize the effects of future land-use decisions, further research on the climatic impacts of forests is essential and should be included in spatially explicit valuation methods (Bebi et al., 2012).

Switzerland is a particular suitable study area for researching the effects of changes in forest cover, since many spatially explicit high-quality data sets are available and forest expansion is an ongoing dominant process of land-use change. The spatially explicit data series available are on land use/land cover (LULC) (1 ha raster), snow cover ( $1 \mathrm{~km})$, global radiation $(2.2 \mathrm{~km})$, albedo change and carbon sequestration (both explicit for biogeographical regions) for the whole area of Switzerland. Forest cover is expanding by $4 \%$ per decade at the country scale and by $8 \%$ per decade in alpine areas (National Forest Inventory, NFI).

Our study design is twofold: first, we use the spatially explicit data sets to show the pattern of RF assuming that each location in Switzerland is facing a transition from agriculturally used open land to forest. This is not related to any particular or realistic scenario; however, the spatial pattern of RF can be of high interest for any land-use policies steering forest-cover change towards desired futures. In Switzerland agricultural subsidies directly influence farmers decisions on whether to keep managing or abandon their land. The latter will usually result in forest expansion. Second, we include the type and location of five different land-use transitions to calculate RF in Switzerland between 1985 and 1997. In summary, we estimate (i) to which extent albedo RF offsets $\mathrm{CO}_{2}$ $\mathrm{RF}$ in different parts of temperate mountainous regions, (ii) how each input parameter influences RF and (iii) what the inclusion of albedo change implies for the greenhouse gas inventory in Switzerland.

\section{Data and methods}

\subsection{Study area}

Switzerland covers an area of $41284 \mathrm{~km}^{2}$ and can be divided into five biogeographical regions (Fig. 1). Each region has biogeographical features that can be found globally at temperate latitudes: (1) Jura - oceanic low mountain range with elevations averaging $800 \mathrm{~m}$ a.s.l.; (2) Plateau - oceanic lowlands with elevations averaging $550 \mathrm{~m}$ a.s.l.; (3) northern Prealps - oceanic subalpine mountain range with elevations averaging $1400 \mathrm{~m}$ a.s.l.; (4) Central Alps - continental alpine mountain range with elevations averaging $2150 \mathrm{~m}$ a.s.l.; (5) southern Prealps - Mediterranean/Insubric line subalpine mountain range with elevations averaging $1500 \mathrm{~m}$ a.s.l. In each region, deciduous forests and mixed deciduous forest dominate at low elevations (mostly Fagus sylvatica), while coniferous forests are dominant at higher elevations (mostly Picea abies).

The Swiss landscape has been strongly affected by several centuries of intensive human land-use (Bürgi and Schuler, 2003; Schneeberger et al., 2007; Gimmi et al., 2009) followed by the widespread abandonment of marginal agricultural land and the subsequent expansion of forest cover since the end of the 19th century (Baur, 2006). Due to unfavorable pedologic and climatic conditions and high slope angles, marginal land and forest expansion are mainly found at higher elevations (Baur, 2006). Land abandonment was the most dominant driver for the establishment of new forest areas; however, a small fraction of forest expansion at the treeline can be attributed to recent climate warming (GehrigFasel et al., 2007). The treeline is not only often the result of former land use but also depends on various climatic factors 


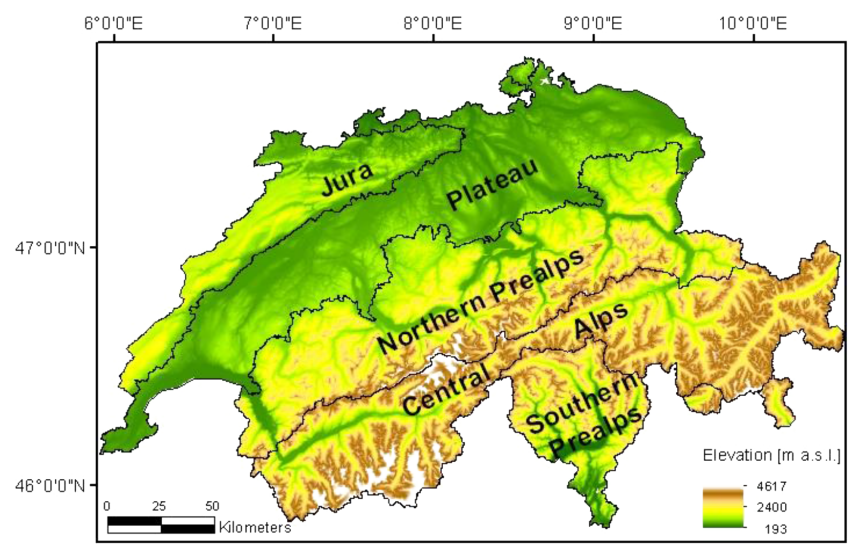

Figure 1. Digital elevation model and biogeographical regions of Switzerland.

and is generally higher in the Central Swiss Alps (approx. 2100-2300 m) than in the northern and southern Prealps (approx. 1800-2000 m) (Fig. 3f; Körner, 2012).

\subsection{Spatial variability of RF and RF of Swiss forest expansion}

We calculated the net RF and the offset of $\mathrm{CO}_{2} \mathrm{RF}$ through albedo $\mathrm{RF}\left(\triangle \mathrm{RF}_{\mathrm{CO}_{2}} / \Delta \mathrm{RF}_{\text {albedo }}\right)$ to show the spatial variability of RF in Switzerland and to calculate RF of Swiss forestcover expansion between 1985 and 1997. To illustrate the pattern of RF in Switzerland we calculated a value of RF for every location in Switzerland, excluding non-vegetated land, water, settlement and areas that lie above the treeline (Fig. 3). These are hypothetical values because we calculated RF for the change from open land to forest for all vegetated areas, and not only for the ones where forest expansion was actually observed. At lower elevations, transitions from intensively used open land to forest are frequent, while in higher elevations transitions from extensively used open land to forest are most likely (Table A4). We considered this by separating our estimation of the hypothetical RF in transitions from intensively used open land to forest below $1000 \mathrm{~m}$ and transitions from extensively used open land to forest above $1000 \mathrm{~m}$. The results of the spatial variability of RF are shown in maps of the study area (Fig. 4c ,d).

To obtain results for RF of forest-cover expansion between 1985 and 1997 in Switzerland we calculated net radiative forcing as the sum of RF for all pixels where forests expanded. This meant including information on the type of forest expansion and on the location of forest expansion:

$\Delta \mathrm{RF}_{\mathrm{ges}}=\frac{\sum_{x=1}^{n} \mathrm{RF}_{x, T}}{A_{\mathrm{E}}}$,

where $\Delta \mathrm{RF}_{\text {ges }}$ is the net RF, $n$ the number of pixels where forests expanded and RF the radiative forcing, which depends on the location $x$ and the type of transition $T$. The sum over RF is divided by the the earth's surface $A_{\mathrm{E}}$ to convert local RF into a global average RF (de Wit et al., 2014).

\subsection{Swiss forest expansion between 1985 and 1997}

We use aerial photographs processed by Swiss Statistics at a spatial resolution of $100 \mathrm{~m}$ to derive changes in LULC. These aerial photographs are from the Swiss Federal Office of Topography and are fully available for the two inventory periods: 1979-1985 and 1992-1997 (Humbel et al., 2010). We reclassified the data of the different inventory periods into five aggregated classes (Rutherford et al., 2008). While 18 classes were aggregated into four classes: closed forest, open forest, extensively and intensively used open land (Fig. 2), the remaining 56 were classified as other and consisted mainly of settlements, water and non-vegetated land (Table A5). The aggregation of the original land-use classes results in a sufficiently large sample of reliable albedo values and carbon stocks in each of the five biogeographical regions and three elevational strata for five relevant and wellestablished land-use classes.

To calculate RF of land-use change between 1985 and 1997, we included five transitions: (1) intensively used open land $\rightarrow$ closed forest, (2) extensively used open land $\rightarrow$ closed forest, (3) intensively used open land $\rightarrow$ open forest, (4) extensively used open land $\rightarrow$ open forest and (5) open forest $\rightarrow$ closed forest. Forest expansion mainly took place in elevations above $1200 \mathrm{~m}$ in the Prealps and the Central Alps (Fig. A1). We focused on transitions where forest cover and carbon stocks increase because these transitions highly exceeded transitions with forest decrease in Switzerland. In fact, Swiss law strongly protects forests, so there have been only a few changes from forest to agriculturally used land during the last 30 years (Bloetzer, 2004, Rutherford et al., 2008).

\section{$2.4 \mathrm{CO}_{2} \mathrm{RF}$}

An increase in carbon stocks in terrestrial ecosystems is related to a sink of atmospheric $\mathrm{CO}_{2}$, followed by a change in the earth's radiation balance. Myhre et al. (1998) developed a parameterization to derive RF, related to a change in the $\mathrm{CO}_{2}$ concentration in the atmosphere, based on radiative transfer schemes:

$\Delta \mathrm{RF}(t)=5.35 \ln \frac{C(t)}{C_{0}}$,

where $\triangle \mathrm{RF}(\mathrm{t})$ is the Radiative Forcing, $C(t)$ is the atmospheric $\mathrm{CO}_{2}$ concentration after perturbation and $C_{0}$ is the unperturbed atmospheric $\mathrm{CO}_{2}$ concentration. Equation (2) can be solved if the $\mathrm{CO}_{2}$ concentration in the atmosphere after perturbation is known.

Following Switzerland's Greenhouse Gas Inventory 1990 2010 (Heldstab et al., 2012), which is based on the Good Practice Guidance for Land Use, Land Use Change and 


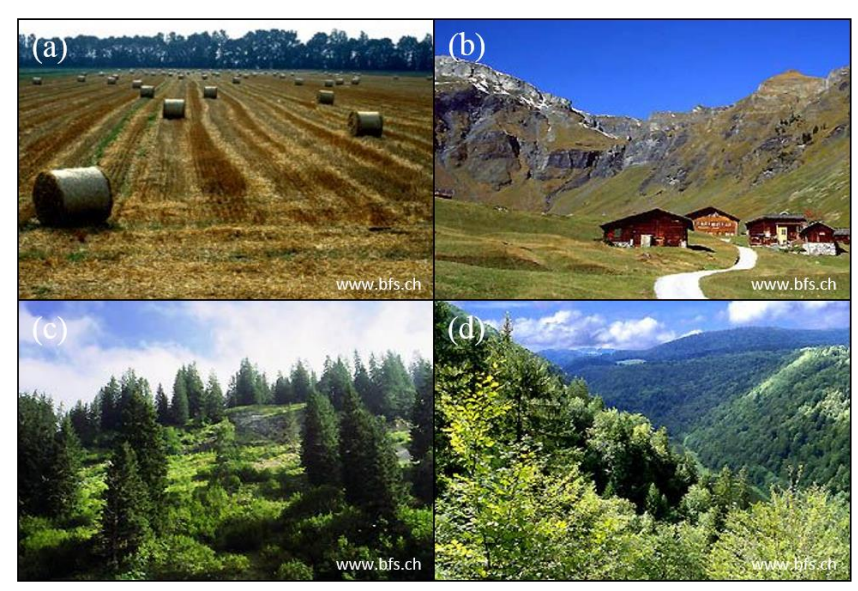

Figure 2. Examples of (a) intensively used open land (b) extensively used open land (c) open forest (d) closed forest.

Forestry (IPCC, 2003), we calculated the carbon stock changes resulting from land-use changes as the differences between the carbon stocks of the land-use categories before and after a transition. This takes into account changes in living plant biomass, dead wood and soil carbon stocks.

Data on carbon stocks in the living biomass and dead wood of closed forests and open forests were derived from the third NFI (Brändli, 2010). The data are based on 6608 field plots measured on a regular sampling $1.4 \mathrm{~km} \times 1.4 \mathrm{~km}$ grid from 2004 to 2006. Two $200 \mathrm{~m}^{2}$ concentric circles are used for trees with diameter at breast height $(\mathrm{DBH}) \geq 12 \mathrm{~cm}$ but $<36 \mathrm{~cm}$, and two $500 \mathrm{~m}^{2}$ concentric circles for trees with $\mathrm{DBH} \geq 36 \mathrm{~cm}$. This results in DBH measurements of approximately 11 trees per plot. On a sub-sample of approximately two trees per plot, the diameter at $7 \mathrm{~m}$ tree height and the tree height are measured. The biomass of all single trees is estimated according to allometric functions. The assessment of stem wood over bark, including stock, coarse branches $(\geq 7 \mathrm{~cm})$ and small branches $(<7 \mathrm{~cm})$ is based on Kaufmann (2001), and that of needles/leaves on Perruchoud et al. (1999). Roots are estimated with equations from Wirth et al. (2004) for coniferous trees and Wutzler et al. (2008) for deciduous trees. Estimates for branches, foliage and roots were derived from the DBH only, while for stem wood over bark including stock, the diameter at $7 \mathrm{~m}$ tree height and the total tree height were also required (Kaufmann, 2001). For this study, only living trees were considered. The NFI data were stratified for each biogeographical region of Switzerland and three elevation strata (Table A2). Open forest is represented by forest plots permanently reduced in stocking, and closed forest by all forest plots minus plots permanently and temporarily reduced in stocking.

The estimates of soil carbon stocks were taken from previous assessments in approximately 1000 soil profiles in forests (Hagedorn et al., 2010; Nussbaum et al., 2012) and 500 soil profiles in open land across Switzerland (Leifeld et al., 2005; Bolliger et al., 2008), where each soil profile in the forest had been sampled according to horizons analyzed for their $\mathrm{C}$ content using a $\mathrm{C} / \mathrm{N}$ analyzer. The bulk density and volumetric stone content measured were used to calibrate pedotransfer functions. The carbon stock changes in soils were calculated as the differences between the stocks of different LULC classes. Since soil carbon stocks in agriculturally used open land and forest correlate fairly well across different altitudes (Sjörgersten-Turner et al., 2011), we decided to use the difference between mean soil carbon stocks in open land and forest for the whole of Switzerland.

Changes in carbon stocks in ecosystems can be related to changes in atmospheric $\mathrm{CO}_{2}$ concentrations by including the molecular masses of carbon, dry air and the mass of the atmosphere (Schwaiger and Bird, 2010; O'Halloran et al., 2012):

$\Delta C_{\mathrm{A}}=\frac{\Delta m_{\mathrm{C}} M_{\mathrm{a}}}{M_{\mathrm{C}} m_{\mathrm{a}}}$,

where $\Delta C_{\mathrm{A}}$ is the change in atmospheric $\mathrm{CO}_{2}$ concentration, $\Delta m_{\mathrm{C}}$ the difference between carbon stocks of two LULC classes, $M_{\mathrm{C}}$ is the molecular mass of carbon, $m_{\mathrm{a}}$ is the mass of the atmosphere and $M_{\mathrm{a}}$ is the molecular mass of dry air. Before using this $\mathrm{CO}_{2}$ value $\left(\Delta C_{\mathrm{A}}\right)$ to calculate $\Delta \mathrm{RF}$ (Eq. 2), we took into consideration the fact that each $\mathrm{CO}_{2}$ pulse emitted to the atmosphere disappears partly in sinks of the global carbon cycle (e.g. oceans). A carbon-pulse response function can be used to describe such fluxes (Forster et al., 2007):

$\operatorname{fr}(t)=a_{0}+\sum_{j=1}^{3} a_{i} e^{\frac{-t}{\tau_{j}}}$,

where $\operatorname{fr}(t)$ is the fraction of a $\mathrm{CO}_{2}$ pulse, which can still be found in the atmosphere after time $t$. Generally, the coefficients $a_{0}$ to $a_{3}$ and $\tau_{1}$ to $\tau_{3}$ have no direct process-based meaning, but are fitting parameters chosen to represent a given model-based carbon-pulse response function (Joos et al., 2013). $\mathrm{CO}_{2}$ sequestration equals negative $\mathrm{CO}_{2}$ pulses $\left(\mathrm{CO}_{2}\right.$ removal from the atmosphere). The carbon-pulse response function can be applied to negative pulses because a reduced $\mathrm{CO}_{2}$ concentration in the atmosphere will reduce the amount of $\mathrm{CO}_{2}$ sequestrated by the terrestrial biosphere and oceans. To estimate how much carbon dioxide from continuous $\mathrm{CO}_{2}$ pulses after time $t$ stays airborne, a widely used convolution function can be applied (Siegenthaler and Oeschger, 1978; Cherubini et al., 2011):

$C(t)=\int_{0}^{t} g\left(t^{\prime}\right) y\left(t-t^{\prime}\right) \mathrm{d} t^{\prime}$,

where $C(t)$ stands for the yearly change in carbon dioxide in the atmosphere that can be exclusively related to carbon sequestration during forest expansion, $g\left(t^{\prime}\right)$ characterizes the carbon sequestration due to forest expansion, depending on the gradient of $\mathrm{CO}_{2}$ uptake during succession and $y\left(t-t^{\prime}\right)$ 
accounts for the reduced uptake of carbon dioxide in the carbon cycle. We estimate the integral using a simple numerical approximation and time intervals of 1 year:

$C_{t}=\sum_{i=1}^{t} g_{i} y_{t-i}$.

We kept the background $\mathrm{CO}_{2}$ concentration fixed to solve the radiative transfer parameterization (Eq. 2) and accordingly used parameters that describe carbon sequestration in the carbon cycle for a fixed $\mathrm{CO}_{2}$ background concentration. The $\mathrm{CO}_{2}$ concentration and parameters for the carbon cycle will, however, change (IPCC, 2001) and it is not clear whether it is necessary to take these changes into account. Joos et al. (2013) showed that radiative forcing was more or less constant when $\mathrm{CO}_{2}$ pulses were emitted to atmospheres with different $\mathrm{CO}_{2}$ background concentrations. They suggest that the carbon uptake per unit atmospheric $\mathrm{CO}_{2}$ decreases not only with a high background concentration of $\mathrm{CO}_{2}$, but also with the RF per unit change in atmospheric $\mathrm{CO}_{2}$. They both decrease in such a way that $\mathrm{RF}$ of a $\mathrm{CO}_{2}$ emission is almost identical at preindustrial and present-day conditions. Keeping background $\mathrm{CO}_{2}$ concentrations and carbon cycle parameters constant thus seems to be a reasonable approximation.

\subsection{Albedo RF}

The yearly radiative forcing $\Delta \mathrm{RF}(\mathrm{t})$ at the top of the atmosphere of an albedo change is calculated (modified from Montenegro et al., 2009) as the seasonal average:

$\Delta \mathrm{RF}(t)=\frac{1}{12} \sum_{t=1}^{12} I_{t} \Delta \alpha_{t}-0.23 I_{t} \Delta \alpha_{t}$,

where $I_{t}$ is the monthly global radiation at the earth surface, $\Delta \alpha_{t}$ is the albedo difference between two LULC classes depending on the monthly fraction of snow cover and 0.23 is a factor to account for the absorption of the reflected radiation in the atmosphere. The first part of Eq. (7) describes which part of the global radiation is absorbed at the surface. The second part describes which part of the reflected short-wave radiation is absorbed in the atmosphere. The factor of 0.23 is that used by Montenegro et al. (2009) who modified the value 0.3 given by Weaver et al. (2001).

We used gridded global radiation (i.e. surface short-wave irradiance) data from MeteoSwiss (MeteoSwiss, 2012) in monthly data sets averaged over the period from 2004 to 2010 to eliminate inter-annual variability. The spatial resolution of the global radiation data set is $2.2 \mathrm{~km}$. The derivation of the global radiation data was based on the Heliosat method (Cano et al., 1986; Beyer et al., 1996; Hammer et al., 2003), applied to Meteosat SEVIRI data. It was verified using highquality surface measurements and sensitivity runs for key input parameters (Durr et al., 2010). The albedo was estimated using the following equation (modified from Barnes and Roy, 2010; Roesch et al., 2002):

$\Delta \alpha(t)=f(t) \Delta \alpha_{\mathrm{S}}+(1-f(t)) \Delta \alpha_{v}$,

where $\Delta \alpha(t)$ is the monthly albedo difference between two LULC classes, $\Delta \alpha_{\mathrm{S}}$ the average albedo difference between two LULC classes when snow covered, $\Delta \alpha_{v}$ the average albedo difference between two LULC classes when snow free and $f(t)$ the fraction of snow cover per month. We used average albedo differences of snow-free and snow-covered albedo differences and not monthly differences for two reasons. First, by far the strongest seasonal trend is related to the presence of snow, which we explicitly included (Zhou et al., 2003). Second, in some months reliable albedo data was missing and we considered the average to be a robust estimate. Since we found that the seasonal variation of the albedos of different LULC classes is similar, the averaging of snow-covered and snow-free albedo differences results in a fairly good approximation (Fig. A2 and A3).

Monthly data sets on snow cover were provided by the Remote Sensing Research Group at the University of Bern. Raw $1 \mathrm{~km}$ data from AVHRR (Advanced Very High-Resolution Radiometer) were processed using an algorithm to estimate the snow cover (Separation of Pixels using Aggregated Rating Over Canada, SPARC). The algorithm was adapted to the mountainous region of the European Alps and verified (Huesler et al., 2012). Again we calculated an average value for each month using data of the years 2002-2009 to eliminate inter-annual variability.

For assigning albedos to different LULC classes, we overlaid NASA's Moderate-resolution Imaging Spectroradiometer (MODIS) $0.5 \mathrm{~km}$ bidirectional reflectance distribution function (BRDF)/albedo product (MCD43A) and gridded $0.1 \mathrm{~km}$ LULC data from the Swiss area statistics aggregated into five categories (see Sect. 2.3). We used MODIS data between 2004 and 2009 and the area statistics from the third inventory period 2004-2009 to ensure a temporal overlap between the albedo and the LULC records. Since not all the LULC data for south-eastern Switzerland are available yet, we complemented the area statistics (2004-2009) with data from the second inventory period (1992-1997) and accepted a temporal displacement for this region.

We applied several different methods for calculating landuse-specific albedos. First, we retained albedo pixels of the highest quality (full BRDF inversion) for our analysis. To reduce the error caused by assigning albedo values to a mixed pixel (several $0.1 \mathrm{~km}$ LULC classes in one $0.5 \mathrm{~km}$ albedo pixel), we only assigned albedo values to a specific LULC class if at least $92 \%$ of the albedo pixel were covered by just one LULC class (similar to Kvalevag et al., 2010). The threshold of $92 \%$ ( 23 out of 25 pixels) is a trade-off between using as many albedo pixels in the study area as possible and at the same time reducing the error due to $8 \%$ random land cover ( 2 out of 25 pixels). If not enough pixels covered by at 
least $92 \%$ of one LULC class were available, we would apply additional methods to calculate specific albedos, accepting the trade-off of using more pixels, but with less quality. For the first step, we included albedo values of lower quality produced with magnitude inversion (Liu et al., 2009). If still not enough pixels were available, we would change the cell size of the area statistics to $0.5 \mathrm{~km}$ (according to the most frequent LULC class within a pixel) and assign albedo values to this new LULC data set. To estimate closed forest albedos, we only used pixels of at least $92 \%$ land cover and the best quality (full BRDF inversion). Open forest values were mainly calculated using lower quality values (magnitude inversion) and the resampled pixels (Table A1). For extensively and intensively used open land, we used the average albedo values for the whole study area because it was not possible to derive specific values for each region (e.g. extensively used open land hardly occurs below $600 \mathrm{~m}$ a.s.l. and intensively used open land hardly occurs above $1200 \mathrm{~m}$ a.s.l.). We accepted a bias of open land albedos in these regions since they were usually not important for LULC change. For instance, LULC change below $600 \mathrm{~m}$ involves almost exclusively intensively used open land.

The MCD43A product is available for free online. It provides atmospherically corrected gridded albedo data for a variety of spectrums. We used broadband white-sky albedo $(0.3-5.0 \mu \mathrm{m})$. In order to distinguish between snow-covered and snow-free areas, we applied the quality flags of the MODIS product MCD43A2. The albedo product MCD43A3 has been produced applying the MODIS BRDF/albedo algorithm (Strahler et al., 1999). This algorithm makes use of 16-days worth of multi-date data from both the Terra and Aqua platforms and a semi-empirical kernel-driven bidirectional reflectance model to determine a global set of parameters describing the BRDF of the land surface (Schaaf, 2010).

\subsection{Temporal signature of RF}

Both albedo RF and $\mathrm{CO}_{2} \mathrm{RF}$ are a function of time. The annual variation of $\mathrm{CO}_{2} \mathrm{RF}$ depends on the carbon-pulse response function and the yearly carbon sequestration in biomass and soil during succession. The annual variation of albedo RF depends on the albedo change during succession. For both carbon sequestration and albedo change we had to rely on the static difference between land-use classes, e.g. open land (as starting point) and closed forests (end of succession). We assumed that carbon sequestration as well as albedo change follow linear trends until they reach an approximately steady state. Since a detailed description of the temporal evolution of albedo change and carbon sequestration is complex and varies with location, we used a simplified scheme in which we assumed that albedo change is complete after 30 years, carbon sequestration in biomass after 50 years and carbon sequestration in soils after 100 years. This seems to be a reasonable approximation since albedo change is likely to end before carbon accumulation in biomass does
(Kirschbaum et al., 2011, de Wit et al., 2013) and carbon sequestration in soils will most likely not end in less than 100 years (Poeplau et al., 2011). We assumed that albedo change and carbon sequestration stop after a certain time; however, interactions with the global carbon cycle will still cause changes in the atmospheric $\mathrm{CO}_{2}$ concentration. Thus, we compared the temporal mean of radiative forcing for two different time horizons, 100 and 1000 years. For the representation of our results, we chose the mean RF in 100 years. The temporal average of RF is useful not only when representing spatial variability but also for a comparison with earlier studies on spatial variability of RF, which did not explicitly include temporal variation (Betts, 2000, Montenegro et al., 2009).

\subsection{Sensitivity analysis}

In a sensitivity analysis we tested how the spatial variability and uncertainty of each input factor influence our results. We based the sensitivity analysis on FAST (Fourier amplitude sensitivity test), developed by Saltelli et al. (1999), and used an implementation (fast99) provided in the R package sensitivity (Pujol et al., 2012). Applying a sensitivity analysis with FAST allowed us to show how varying input factors influenced the variance of the output including first-order effects and interactions for each parameter. We approximated input as either uniform or normal distributed, according to the distribution of each input factor in the study area. We assumed input factors were uncorrelated, which only holds to a certain degree since, for example, all factors either increase or decrease with elevation. We separated our sensitivity analysis into two parts. First, we applied data on spatial variability. Each of the factors, carbon sequestration, snow cover, global radiation, albedo difference (snow covered) and albedo difference (snow free) vary spatially and temporally. We averaged every input factor temporally and applied the spatial minimum and maximum of each factor to the function fast 99 (Table A3). The minimum and maximum of snow-covered albedo differences are, e.g. 0.208 (Alps 600-1200) and 0.375 (Jura > 1200). This analysis showed which factor had the greatest influence on the variation in RF caused by change in forest cover at a specific location. In a second sensitivity analysis, we applied the uncertainty values of each factor (Table A3). The sensitivity analysis of uncertainties, represented by random sampling and measurement errors, indicates which parameter causes high or low uncertainty in the output. 

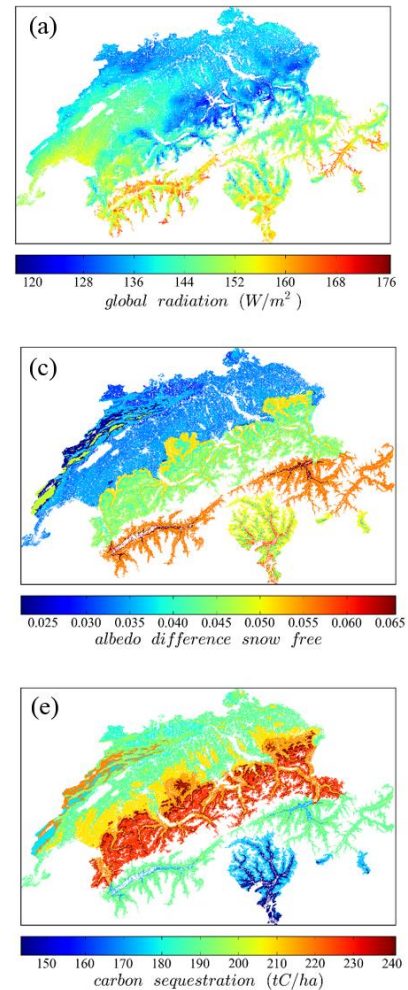
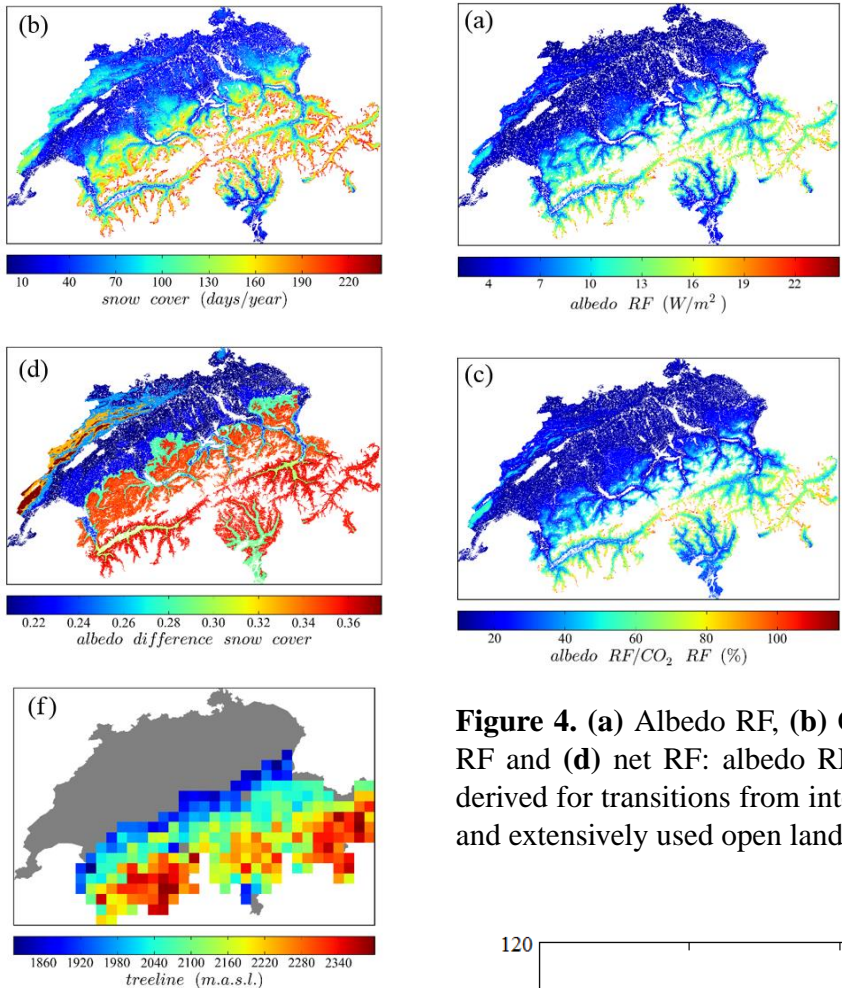

Figure 3. (a) Mean yearly global radiation. (b) Days with snow cover per year. (c) Albedo difference without snow (difference between intensively and extensively used open land and closed forest). (d) Albedo difference with snow (difference between intensively and extensively used open land and closed forest). (e) Carbon sequestration (difference between intensively and extensively used open land and closed forest). (f) Treeline elevation calculated using the Swiss area statistics of 1997 and applying the method of Paulsen and Körner (2001).

\section{Results}

In the forest, average $\mathrm{C}$ stocks in biomass ranged from 95 to $170 \mathrm{tC} \mathrm{ha}^{-1}$ (NFI). In the soil (mineral soil $0-100 \mathrm{~cm}+$ organic layer) the average across Switzerland was $143 \mathrm{tc} \mathrm{ha}^{-1}$ (Nussbaum et al., 2012). In the intensively used open land, the average value for biomass was $4.34 \mathrm{tc} \mathrm{ha}^{-1}$ (Heldstab et al., 2012) and $91 \mathrm{tc} \mathrm{ha}^{-1}$ in the soils. In comparison, the $\mathrm{C}$ stocks of the extensively used open land amounted to $7 \mathrm{tc} \mathrm{ha}^{-1}$ in the biomass and $63 \mathrm{tc} \mathrm{ha}^{-1}$ in the soil. Minimum and maximum carbon sequestration in Switzerland of transitions from intensively or extensively used open land to closed forest thus ranged from 143 to $241 \mathrm{tc} \mathrm{ha}^{-1}$ (Fig. 3e). This corresponded to a $\mathrm{CO}_{2} \mathrm{RF}$ of -16 to $-27 \mathrm{~W} \mathrm{~m}^{-2}$ (Fig. $4 \mathrm{~b}$ ).

The albedos of snow-covered closed forests ranged from 0.168 to 0.267 , while those of snow-free closed forests ranged from 0.101 to 0.139 . Similarly, the albedos of snowcovered open forests ranged from 0.217 to 0.307 and those of snow-free open forests from 0.117 to 0.141 (Fig. 5). The average albedo of intensively used open land was $0.170 / 0.475$
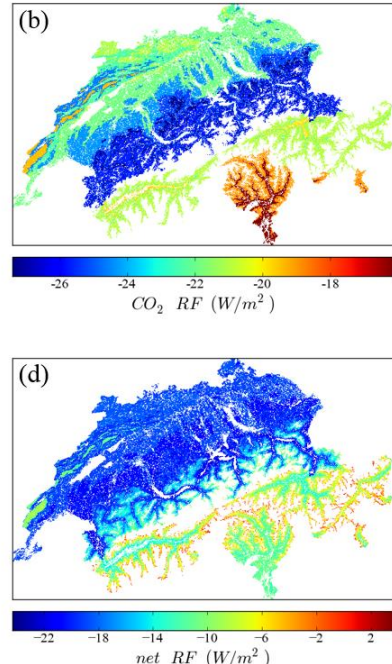

Figure 4. (a) Albedo RF, (b) $\mathrm{CO}_{2} \mathrm{RF}$, (c) offset: albedo RF/CO2 $\mathrm{RF}$ and (d) net RF: albedo RF plus $\mathrm{CO}_{2} \mathrm{RF}$. All data sets were derived for transitions from intensively used open land $(<1000 \mathrm{~m})$ and extensively used open land ( $>1000)$ to closed forest.

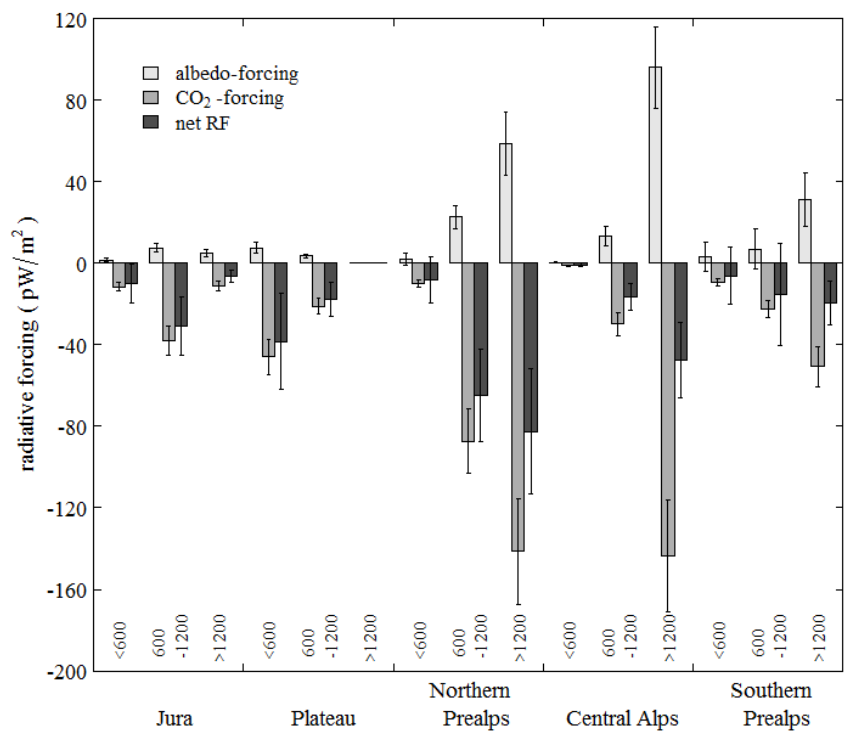

Figure 5. Radiative forcings of the forest expansion between 1985 and 1997 for three elevations in the biogeographical regions Jura, Plateau, northern Prealps, Central Alps and southern Prealps.

(snow free/snow covered) while that of extensively used open land was $0.154 / 0.549$ (snow free/snow covered). The albedo differences between transitions from intensively or extensively used open land to closed forest thus ranged from 0.208 to 0.375 (snow covered) and from 0.023 to 0.066 (snow free) (Fig. 3c, d). Albedo change in Switzerland caused albedo RF ranging from 2 to $21 \mathrm{~W} \mathrm{~m}^{-2}$ (Fig. 4a).

The net $\mathrm{RF}$ at different locations in the study area ranged from -24 to $2 \mathrm{~W} \mathrm{~m}^{-2}$ and the offset of $\mathrm{CO}_{2} \mathrm{RF}$ caused by 

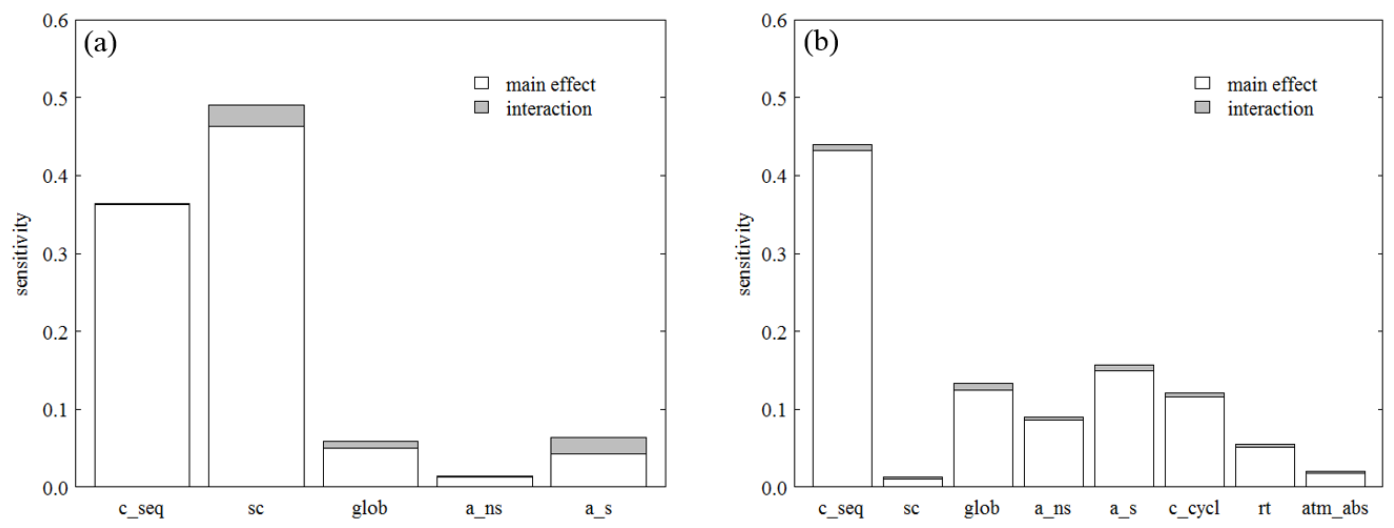

Figure 6. Global sensitivity analysis FAST: (a) sensitivity analysis of spatial variability of $c_{\mathrm{seq}}$ (carbon sequestration), $s_{\mathrm{c}}$ (snow cover), glob (global radiation), $a_{\mathrm{ns}}$ (albedo difference no snow cover) and $a_{\mathrm{S}}$ (albedo difference snow covered), (b) sensitivity analysis of uncertainty for each pixel: $c_{\mathrm{seq}}, s c$, glob, $a_{\mathrm{ns}}, a_{\mathrm{S}}, c_{\text {cycle }}$ (carbon cycle), $r_{\mathrm{t}}$ (radiative transfer) and $a t m_{\text {absorb }}$ (atmospheric absorption).

albedo RF differed between 11 and 109\%. The differences were particularly marked on an elevational gradient and between the five biogeographical regions. Below an elevation of $600 \mathrm{~m}$ a.s.l., the albedo RF offset $\mathrm{CO}_{2} \mathrm{RF}$ by $15 \%$ on average. Between 600 and $1200 \mathrm{~m}$, the offset was $22 \%$ and above $1200 \mathrm{~m} 54 \%$. The highest RF was observed in high snowrich alpine regions. In the Central Alps, $13 \%$ of all possible LULC areas had an offset of more than $80 \%$. In the southern Prealps $7 \%$ of all possible LULC areas had an offset higher than $80 \%$. In the Central Alps, as well as in the southern Prealps, we found areas where net RF was positive. However, these areas amounted to less than $0.2 \%$ of both regions. We only found positive RF at elevations above $1850 \mathrm{~m}$. The albedo RF was the lowest in the Plateau region and at low elevations of the Jura. Albedo RF accounted, on average, for less than $14 \%$ of the $\mathrm{CO}_{2} \mathrm{RF}$ in these regions. The lowest net $\mathrm{RF}$ (average $-20 \mathrm{~W} \mathrm{~m}^{-2}$ ) was found in the northern Prealps below $1200 \mathrm{~m}$. Above $1200 \mathrm{~m}$ the net RF in the northern Prealps was lower than in southern Prealps and Central Alps, although the snow cover in the northern Prealps was persistent. However, the effect of a persistent snow cover in the northern Prealps was outweighed by the low global radiation, the low treeline and the high carbon sequestration in this alpine region (see Fig. 3).

The net RF forcing of forests across the mountainous terrain in Switzerland strongly depended on the elevation (Fig. 5). The albedo RF increased with altitude, with several factors contributing to this increase (Fig. 3). First, global radiation increased with altitude, reaching maxima in continental parts of the Alps. Second, albedo (snow free, snow covered) of forests was in general lower above $1200 \mathrm{~m}$ a.s.l. (where coniferous species dominate). Third, both snow cover and snow-cover period strongly increased with altitude. The carbon sequestration potential of forests decreased with altitude (due to unfavorable climatic conditions towards treeline).
Radiative forcing depended not only on location but also on the type of LULC transition. LULC transitions from open land to open forest had a higher offset (approx. 80\%) than transitions from already established open forest to closed forest (approx. 40\%). Transitions from open forest to closed forest were generally associated with relatively high change in carbon stocks (around $70 \mathrm{tc} \mathrm{ha}^{-1}$ ), and relatively small albedo change (for snow-covered albedo $<0.06$ and for snow-free albedo $<0.01$ ).

Between 1985 and 1997, all five types of LULC transitions (Table A4) took place on an area of 24000 ha. More than $70 \%$ of them were situated above $1000 \mathrm{~m}$. Above $1000 \mathrm{~m}$, the most frequent transition was the one from open to closed forest $(50 \%)$, followed by transitions from extensively used open land to open forest $(20 \%)$ and from extensively used open land to closed forest (13\%). Land-use change occurred especially in high altitude regions where albedo RF strongly offsets $\mathrm{CO}_{2} \mathrm{RF}$ (Fig. 5). At the same time, the most frequent transition was the one from open forest to closed forest, where albedo RF had the least influence on net RF. In summary, the $\mathrm{CO}_{2} \mathrm{RF}$ for all land-use transitions that were part of the forest expansion and succession between 1985 and 1997 in Switzerland was reduced by approximately $40 \%$, if the albedo RF is taken into account.

The net RF varied greatly on small spatial scales. In our study area, the parameter that had the most significant influence on the spatial variability of RF was snow cover, followed by carbon sequestration, difference in snow-covered albedo, global radiation and difference in snow-free albedo (Fig. 6a). Thus, if the average snow cover (in days year ${ }^{-1}$ ) and carbon sequestration at a certain location were known, the net RF and the offset of $\mathrm{CO}_{2} \mathrm{RF}$ through albedo RF could be estimated well without including all factors in an explicit calculation. We found that the offset of $\mathrm{CO}_{2} \mathrm{RF}$ can only be higher than $50 \%$ if the snow cover lasted over 120 days year $^{-1}$. An increase in snow cover caused an exponential 
increase in albedo RF. Because, first, persistent snow cover was found in regions with high global radiation and second because the longer snow covered the surface, the longer it would be present during the days with high global radiation in March, April and May.

The uncertainty of net radiative forcing was mainly attributed to uncertainties in carbon sequestration, followed by snow-covered albedo difference, global radiation and snowfree albedo difference. The main effects of uncertainty related to each input factor were much more relevant than the contribution of interactions between all input factors (Fig. 6a).

\section{Discussion}

Our detailed assessment of radiative forcing across Switzerland shows that the albedo RF increases with increasing altitude, which offsets the $\mathrm{CO}_{2} \mathrm{RF}$ at high elevations with long snow-covered periods, high global radiation and low carbon sequestration. The altitudinal RF gradient in Switzerland is very strong in comparison to the latitudinal gradient in boreal regions (Betts, 2000; Montenegro et al., 2009). The persistence of snow cover increases with increasing elevation and increasing latitude. However, while persistence of snow cover and global radiation are usually positively correlated in mountainous regions, causing high RF, they are negatively correlated in boreal regions. The strong altitudinal RF gradient found in this study is likely to be even more pronounced if altitudinal changes in forest structure and its influence on albedo and carbon sequestration are included on higher resolution because forests with very low carbon stocks can also have a low albedo (de Wit et al., 2014).

However, despite the general increase of RF with elevation, each biogeographical region has its specific characteristics. While the Jura and Plateau (under $600 \mathrm{~m}$ a.s.1.) are characterized, respectively, by albedos of 0.136 and 0.139 (snow free) and 0.272 and 0.276 (snow covered), the albedo in the southern Prealps under $600 \mathrm{~m}$ is comparably low $(0.112$ and 0.185 , respectively). This regional difference may be related to the different forest types and soil characteristics. Whereas beech dominates in the Jura and the Plateau, many stands in the southern Prealps are dominated by chestnut. Moreover, forest soils in the lowlands of the southern Prealps contain particularly high fractions of black fire derived carbon (Eckmeier et al., 2010). The darker soil colour may lower the albedo in addition to differences in the canopy.

Our spatially highly resolved estimates of RF are in agreement with the results of Betts (2000) and Montenegro et al. (2009) which are based on much coarser resolutions. In Betts (2000), the two pixels encompassing Switzerland show a net carbon sequestration of 100-150 and 150-200 tc ha ${ }^{-1}$ associated with reforestation of pasture, while in Montenegro et al. (2009), the pixels indicate a drawdown ranging between 100-150 tc ha ${ }^{-1}$ (maximum scenario) and 0-
$20 \mathrm{tc} \mathrm{ha}^{-1}$ (minimum scenario). However, many pixels are missing in alpine regions. In our study, we found similar values for the drawdown with values ranging from -10 to $160 \mathrm{tc} \mathrm{ha}^{-1}$ (minus 10 indicates emission instead of drawdown).

Small-scale variability, especially in topographically complex areas, was not captured in these former studies. Here, we used data on global radiation and snow cover on a resolution of $2.2 \mathrm{~km}$ (MeteoSwiss) and $1 \mathrm{~km}$ (Huesler et al., 2012). To calculate differences in carbon sequestration and albedo, we relied on a biogeographical categorization and altitudinal stratification, which are based on major differences in vegetation and other ecological factors (Gutersohn, 1973; Wohlgemuth, 1996). Although the spatial resolution was high in our study, it should be refined further to allow, for instance, a comparison of RF on northern and southern slopes and a better capture of forest types and structures near the treeline.

The global sensitivity analysis with FAST showed that interactions between the input parameters were small in comparison to the main effects of each parameter. Thus, we verified the results of our global sensitivity analysis in a local analysis by estimating the partial derivates for each factor. Both analyses showed good agreement since not only the interactions but also non-linear effects had little influence. The amount of RF at a specific location is essentially influenced by carbon sequestration and snow cover (Fig. 6a). These two factors are good indicators for estimating the amount of RF. Global radiation and snow-covered albedo are also important, but they influence RF five times less than carbon sequestration and even seven times less than snow cover. The factors with the most potential for improving our results are better estimates of carbon sequestration (Fig. 6b), followed by reducing albedo uncertainty and the global radiation. The average parameter for atmospheric absorption (0.23) could be replaced by a spatially explicit parameter. Including a spatially explicit parameter for atmospheric absorption would probably increase the elevation gradient of RF, because atmospheric absorption should be higher in low elevations than in high elevations. According to our sensitivity analysis and Bright and Kvalevag (2013) improving data on atmospheric absorption will have a relatively small influence on the results.

The sensitivity analysis with FAST is based on uncertainty estimates because exact values are not available. For example, MODIS values can be assigned to an average uncertainty of $10 \%$ (O'Halloran et al., 2012, Strahler et al., 1999). This uncertainty is likely to be much higher in topographically complex areas than in even terrain as the algorithm used to produce albedo values only indirectly accounts for topography. Moreover, the uncertainties associated with the different input parameters do not always refer to the same statistical measures and are thus not completely consistent (references of uncertainties are listed in the Table A3).

Regarding the different time horizons, RF increased by $17 \%$ for a time horizon of 1000 years compared with a 
horizon of 100 years. Larger time horizons increased RF since $\mathrm{CO}_{2} \mathrm{RF}$ constantly decreased due to interactions of atmospheric $\mathrm{CO}_{2}$ with the carbon cycle, while albedo $\mathrm{RF}$ became constant after forests reached a steady state. Since we used a time horizon of 100 years, we rather underestimated albedo RF. This apparently goes against the findings of Schaeffer et al. (2006) and Kirschbaum et al. (2011) who both argue that $\mathrm{CO}_{2} \mathrm{RF}$ becomes more dominant for larger time horizons. However, they consider relatively short time periods (including rotations) where carbon sequestration does not end before the forests are removed. We think it is also necessary to include large time horizons when estimating RF, but it is of course an oversimplification to assume a fixed state after transition, since forests are frequently disturbed (e.g. O'Halloran et al., 2012). Over longer periods snow cover will be less persistent in the Alps, which will potentially decrease the albedo RF (de Wit et al., 2013; Pitman et al., 2011).

The maps of the possible carbon sequestration and albedo of forests in each biogeographical region (Fig. 3) reflect mainly ecosystem characteristics. However, forests in Switzerland have long been under permanent anthropogenic influence and are thus not in a naturally balanced equilibrium, i.e. at the end of succession. For example, forests at high elevations in the Jura are often used for pasturing. Hence, they are less dense and sequester less carbon than they would if left to develop as undisturbed forests. The relationship between albedo RF, $\mathrm{CO}_{2} \mathrm{RF}$ and net RF will thus always depend on the actual and previous forest and land management. Our analysis of transitions from extensively used open land to closed forest and open forest corroborates this conclusion. The results indicated that the climatic benefit will be smaller if forests are kept in an open structure (e.g. due to pasturing) than when the canopy closes during succession. These findings are in line with former studies that estimate the effects of succession and forest structure on RF and show that changes in carbon stocks and changes in albedo are not linearly related (Kirschbaum et al., 2011; Bernier et al., 2011).

Our results should be valuable for future studies on the climatic impacts of LULUCF, especially for comparing and evaluating the results from climate models since our results are mainly based on satellite and field data. They should also be valuable for assessing the ecosystem (climate) service of forests in temperate mountains, i.e. for addressing the question of whether forest expansion in these regions is beneficial for climate or not. However, the interpretation of RF values has to be done carefully. First, the concept of radiative forcing has been developed to compare the impact of different forcing agents on the global mean temperature (Hansen et al., 2005). When applied at the regional and local scales one should keep in mind that the comparison of different forcing agents is far from being straightforward. For instance, the impact of albedo will remain mostly local while those from $\mathrm{CO}_{2}$ will be globally distributed and therefore diluted. Fur- thermore, the climate sensitivities of $\mathrm{CO}_{2} \mathrm{RF}$ and albedo RF may differ (Davin et al., 2007).

Finally, it is important to note that our study does not account for all possible effects of forests on climate such as changes in evapotranspiration, surface roughness, and impacts on aerosols and other gases than $\mathrm{CO}_{2}$. The uptake of $\mathrm{CH}_{4}$ during forest expansion in the Alps increased according to Hiltbrunner et al. (2012), which adds to a negative $\mathrm{CO}_{2} \mathrm{RF}$. This effect is, however, one magnitude smaller than the effect of $\mathrm{CO}_{2}$ sequestration. The effect of a changing aerosol concentration, providing cooling (through cloud formation), may be very important (Spracklen et al., 2008). Changes in evapotranspiration and surface roughness, due to forest expansion, have a cooling impact in many geographical contexts (Bonan, 2008; Luyssaert et al., 2014), but we did not include the impacts of these changes in our study. In general, the influence of evapotranspiration and surface roughness will be low in those areas where snow cover plays an important role (Bonan, 2008; Bathiany et al., 2010; Gibbard et al., 2005; Lee et al., 2011). Hence, these effects will be more important at low elevations (e.g. on the Swiss Plateau) than at high elevations in the Alps. The gap between the benefits of forest expansion at low and high elevations may thus become even wider if evapotranspiration and surface roughness are also integrated.

\section{Conclusions}

In the temperate mountainous regions of Switzerland, the net RF associated with changes in forest cover varies greatly on small spatial scales. At low elevations, with low to moderate snow cover, $\mathrm{RF}$ is strongly negative due to a dominance of $\mathrm{CO}_{2} \mathrm{RF}$. At high elevations in continental regions with persistent snow cover, a very high global radiation, low carbon sequestration and low albedos of mostly evergreen tree species, RF can be positive. As a consequence, both clearly negative and positive values of RF can be found within a horizontal distance of $5 \mathrm{~km}$ in alpine valleys. Therefore, the climatic benefits of changes in forest cover can only be properly assessed using data at a high spatial resolution.

Our results indicate that it is very important to include albedo RF when estimating the impact on climate of changes in forest cover. Maps of RF, such as those produced in this study, indicate where climatic benefits from changes in forest cover can be expected and where not. In the Swiss Alps, the relevance of albedo RF is especially high because most transitions from open land to forest occur in regions where albedo RF causes a strong offset of $\mathrm{CO}_{2} \mathrm{RF}$. Practitioners and politicians who need information about ecosystem services on local and regional scales should take into account that RF in the Swiss Alps mainly depends on the persistence of snow cover and the potential for carbon sequestration. Moreover, late successional forest-cover changes from open forests to closed forests are more beneficial for climate than early successional changes. 
Our results could be improved if changes in evapotranspiration, surface roughness, aerosols and gases other than $\mathrm{CO}_{2}$ were included. To determine the impacts of RF better, however, further advances in climate modelling are necessary. A promising approach could thus be the coupling of regional climate models with global climate models. Regional models are able to simulate all the effects of changes in land use on climate (including evapotranspiration, surface roughness and so on) on a small scale. Coupling regional models with global models allows the integration of feedbacks with the global circulation. This could help to close the gap between $\mathrm{RF}$ and temperature changes, and thus answer the question about where temperature changes caused by RF can be expected and how much change is likely. 


\section{Appendix A}

Table A1. Albedo of forest (snow, no snow) and open forest (snow, no snow) and corresponding standard errors (SE) of each biogeographical region. Values marked with ${ }^{*}$ were derived using majority pixels and/or magnitude inversion (see chapter albedo RF), all other values have been derived using $92 \%$ pixel cover and full inversion. Numbers 1-3 behind the biogeographical regions indicate the elevation (1 is below $600 \mathrm{~m}, 2$ is $600-1200 \mathrm{~m}, 3$ is above $1200 \mathrm{~m}$ ).

\begin{tabular}{|c|c|c|c|c|c|c|c|c|}
\hline \multirow[t]{2}{*}{ Region } & \multicolumn{4}{|c|}{ Forest } & \multicolumn{4}{|c|}{ Open forest } \\
\hline & Snow & $\operatorname{SE}(\%)$ & Not Snow & $\mathrm{SE}(\%)$ & Snow & $\mathrm{SE}(\%)$ & Not Snow & $\operatorname{SE}(\%)$ \\
\hline Jura 1 & 0.263 & 1.30 & 0.139 & 0.08 & NA & NA & NA & NA \\
\hline Jura 2 & 0.221 & 0.50 & 0.133 & 0.04 & $0.303^{*}$ & $1.80^{*}$ & $0.141^{*}$ & $0.23^{*}$ \\
\hline Jura 3 & 0.175 & 0.64 & 0.109 & 0.12 & $0.232^{*}$ & $0.67^{*}$ & $0.117^{*}$ & $0.13^{*}$ \\
\hline Plateau 1 & 0.266 & 0.61 & 0.136 & 0.03 & NA & NA & NA & NA \\
\hline Plateau 2 & 0.251 & 0.53 & 0.134 & 0.05 & NA & NA & NA & NA \\
\hline Plateau 3 & NA & NA & 0 & NA & NA & NA & NA & NA \\
\hline Northern Prealps 1 & 0.240 & 3.16 & 0.127 & 0.45 & NA & NA & NA & NA \\
\hline Northern Prealps 2 & 0.194 & 0.38 & 0.118 & 0.06 & $0.217^{*}$ & $2.36^{*}$ & $0.114^{*}$ & $0.49^{*}$ \\
\hline Northern Prealps 3 & 0.203 & 0.40 & 0.112 & 0.11 & $0.275^{*}$ & $0.42^{*}$ & 0.121 & 0.095 \\
\hline Central Alps 1 & $0.168^{*}$ & $2.1^{*}$ & 0.107 & 1.31 & $0.353^{*}$ & $15.7^{*}$ & $0.141^{*}$ & $0.58^{*}$ \\
\hline Central Alps 2 & 0.174 & 0.61 & 0.104 & 0.15 & $0.285^{*}$ & $3.09^{*}$ & $0.134^{*}$ & $0.18^{*}$ \\
\hline Central Alps 3 & 0.192 & 0.23 & 0.101 & 0.08 & $0.274^{*}$ & $0.33^{*}$ & $0.118^{*}$ & $0.068^{*}$ \\
\hline Southern Prealps 1 & $0.185^{*}$ & $4.9^{*}$ & 0.111 & 0.23 & NA & NA & $0.127^{*}$ & $0.78^{*}$ \\
\hline Southern Prealps 2 & 0.190 & 3.13 & 0.121 & 0.07 & $0.258^{*}$ & $3.28^{*}$ & $0.126^{*}$ & $0.27^{*}$ \\
\hline Southern Prealps 3 & 0.194 & 0.78 & 0.107 & 0.12 & $0.307^{*}$ & $0.50^{*}$ & 0.119 & 0.089 \\
\hline
\end{tabular}

Table A2. Carbon stocks of closed forests and open forests in biomass and soils. The standard errors (SEs) refer to the deviation from the sample mean in every biogeographical region. Not included are errors of the model parameters which have been used to derive carbon stocks from tree measurements.

\begin{tabular}{lrrrr}
\hline Region & \multicolumn{3}{c}{ Forest } & \multicolumn{2}{c}{ Open forest } \\
\hline & $\begin{array}{r}\text { biomass } \\
\left(\mathrm{tC} \mathrm{ha}^{-1}\right)\end{array}$ & $\begin{array}{r}\text { SE } \\
(\%)\end{array}$ & $\begin{array}{r}\text { biomass } \\
\left(\mathrm{tC} \mathrm{ha}^{-1}\right)\end{array}$ & $\begin{array}{r}\text { SE } \\
(\%)\end{array}$ \\
\hline Jura 1 & 134.1 & 4.6 & $\mathrm{NA}$ & $\mathrm{NA}$ \\
Jura 2 & 144.3 & 2.3 & 101.27 & 27.2 \\
Jura 3 & 103.7 & 5.5 & 68.44 & 13.4 \\
Plateau 1 & 140.4 & 2.7 & 21.08 & 51.0 \\
Plateau 2 & 159.7 & 3.2 & 92.80 & 46.2 \\
Plateau 3 & 137.58 & 14.1 & 71.26 & 33.6 \\
Northern Prealps 1 & 169.8 & 9.5 & $\mathrm{NA}$ & $\mathrm{NA}$ \\
Northern Prealps 2 & 166.8 & 2.7 & 85.60 & 22.7 \\
Northern Prealps 3 & 152.5 & 4.5 & 72.21 & 11.0 \\
Central Alps 1 & 122 & 11.2 & $\mathrm{NA}$ & $\mathrm{NA}$ \\
Central Alps 2 & 124.7 & 4.0 & 70.41 & 29.8 \\
Central Alps 3 & 115.5 & 2.3 & 57.90 & 7.9 \\
Southern Prealps 1 & 95.2 & 6.8 & $\mathrm{NA}$ & $\mathrm{NA}$ \\
Southern Prealps 2 & 94.7 & 4.7 & 37.40 & 39.3 \\
Southern Prealps 3 & 100.6 & 4.5 & 41.60 & 11.6 \\
\hline
\end{tabular}


Table A3. Spatial variability and uncertainties applied in the sensitivity analysis.

\begin{tabular}{|c|c|c|}
\hline & Spatial variability & $\begin{array}{l}\text { Uncertainty } \\
\text { (standard deviation) }\end{array}$ \\
\hline Carbon sequestration $\left[\mathrm{tC} \mathrm{ha}^{-1}\right]$ & $143-241$ & $\begin{array}{l}+/-35 \% \\
\text { (Hagedorn et al., 2010; } \\
\text { Heldstab et al., 2012) }\end{array}$ \\
\hline Snow cover [days year ${ }^{-1}$ ] & $10-240$ & $\begin{array}{l}+/-10 \% \\
\text { (Husler et al., 2012) }\end{array}$ \\
\hline Global radiation $\left[\mathrm{W} \mathrm{m}^{-2}\right]$ & $117-180$ & $\begin{array}{l}+/-28 \% \\
\text { (Durr et al., 2010) }\end{array}$ \\
\hline Albedo snow covered & $0.208-0.375$ & $\begin{array}{l}+/-36 \% \\
\text { (Combined error of } \\
\text { MODIS data and meth- } \\
\text { ods } \\
\text { for assigning LULC } \\
\text { specific albedos) }\end{array}$ \\
\hline Albedo snow free & $0.025-0.066$ & $\begin{array}{l}+/-28 \% \\
\text { (Combined error of } \\
\text { MODIS data and meth- } \\
\text { ods } \\
\text { for assigning LULC } \\
\text { specific albedos) }\end{array}$ \\
\hline Carbon cycle & - & $\begin{array}{l}+/-15 \% \\
\text { (Joos et al., 2013) }\end{array}$ \\
\hline Radiative transfer & - & $\begin{array}{l}+/-10 \% \\
\text { (Myhre et al., 1998) }\end{array}$ \\
\hline Atmospheric absorption & - & $\begin{array}{l}+/-30 \% \\
\text { radiative transfer tests* }\end{array}$ \\
\hline
\end{tabular}

* For the uncertainty in atmospheric absorption, we relied on experiments with the Fu and Liou online model (Fu and Liou, 2005). We tested different scenarios of cloudiness, aerosol concentration and elevation to determine how much atmospheric absorption could vary over Switzerland. 
Table A4. Area affected by each type of transition between 1985 and 1997 . Numbers 1-3 behind the biogeographical regions indicate the elevation ( 1 is below $600 \mathrm{~m}, 2$ is $600-1200 \mathrm{~m}, 3$ is above $1200 \mathrm{~m}$ ).

\begin{tabular}{|c|c|c|c|c|c|c|}
\hline \multirow{2}{*}{$\begin{array}{l}\text { Region } \\
\text { Biogeo- } \\
\text { graphical } \\
\text { region }\end{array}$} & \multicolumn{6}{|c|}{ Area affected by each transition between 1985 and 1997 [in ha] } \\
\hline & $\begin{array}{r}\text { Intensively } \\
\text { used open } \\
\text { land to } \\
\text { closed forest }\end{array}$ & $\begin{array}{r}\text { Extensively } \\
\text { used open } \\
\text { land to } \\
\text { closed forest }\end{array}$ & $\begin{array}{r}\text { Intensively } \\
\text { used open } \\
\text { land to } \\
\text { open forest }\end{array}$ & $\begin{array}{r}\text { Extensively } \\
\text { used open } \\
\text { land to } \\
\text { open forest }\end{array}$ & $\begin{array}{r}\text { Open } \\
\text { forest } \\
\text { to closed } \\
\text { forest }\end{array}$ & $\begin{array}{r}\text { Forest } \\
\text { expansion } \\
\text { (sum of all } \\
\text { transitions) }\end{array}$ \\
\hline Jura 1 & 116 & 31 & 98 & 35 & 106 & 386 \\
\hline Jura 2 & 113 & 238 & 73 & 330 & 522 & 1276 \\
\hline Jura 3 & 1 & 46 & 1 & 155 & 490 & 693 \\
\hline Plateau 1 & 613 & 87 & 379 & 52 & 264 & 1395 \\
\hline Plateau 2 & 232 & 60 & 110 & 44 & 85 & 531 \\
\hline Plateau 3 & NA & NA & NA & NA & 1 & 1 \\
\hline Northern Prealps 1 & 109 & 21 & 78 & 13 & 53 & 274 \\
\hline Northern Prealps 2 & 321 & 497 & 295 & 401 & 959 & 2473 \\
\hline Northern Prealps 3 & 34 & 955 & 77 & 1180 & 2476 & 4722 \\
\hline Central Alps 1 & 4 & 4 & 6 & 11 & 29 & 54 \\
\hline Central Alps 2 & 93 & 101 & 267 & 154 & 679 & 1294 \\
\hline Central Alps 3 & 102 & 739 & 291 & 1700 & 3687 & 6519 \\
\hline Southern Prealps 1 & 61 & 25 & 145 & 22 & 196 & 449 \\
\hline Southern Prealps 2 & 76 & 77 & 170 & 135 & 731 & 1189 \\
\hline Southern Prealps 3 & 23 & 274 & 71 & 604 & 1541 & 2513 \\
\hline
\end{tabular}


Table A5. Aggregation of land-use classes from Swiss Arealstatistik (ASCH85, ASCH97 and ASCH04) adapted from Rutherford et al. (2008).

\begin{tabular}{|c|c|c|c|c|}
\hline $\begin{array}{l}\text { Aggregated } \\
\text { class }\end{array}$ & Area [ha] & $\begin{array}{l}\text { Classes from Swiss land-use } \\
\text { statistics }\end{array}$ & $\begin{array}{l}\text { Area } \\
\text { [ha] }\end{array}$ & Broad definition \\
\hline $\begin{array}{l}\text { Closed } \\
\text { forest }\end{array}$ & 1121544 & $\begin{array}{l}\text { Afforestation, } 52 \\
\text { Forest dieback, } 54 \\
\text { Normal forest, } 50 \\
\text { Slender forest, } 14 \\
\text { Bushes, } 57 \\
\text { Groves and hedges, } 58\end{array}$ & $\begin{array}{l}3349 \\
14851 \\
962312 \\
44711 \\
60514 \\
35807\end{array}$ & $\begin{array}{l}\text { Vegetation height }>3 \mathrm{~m} \text {, cover } \\
\text { density }>60 \% \text {, composed of } \\
\text { tree species }\end{array}$ \\
\hline $\begin{array}{l}\text { Open } \\
\text { forest }\end{array}$ & 150101 & $\begin{array}{l}\text { On non-agriculturally used } \\
\text { land, } 56 \\
\text { On agriculturally used land, } 55 \\
\text { Groups of trees on agricultur- } \\
\text { ally used land, } 59 \\
\text { Groups of trees on non- } \\
\text { agriculturally used land, } 60\end{array}$ & $\begin{array}{l}52825 \\
24108 \\
38157 \\
35011\end{array}$ & $\begin{array}{l}\text { Vegetation height }>3 \mathrm{~m} \text {, cover } \\
\text { density } 20-60 \% \text {, composed of } \\
\text { tree species }\end{array}$ \\
\hline $\begin{array}{l}\text { Extensively } \\
\text { used open land }\end{array}$ & 767842 & $\begin{array}{l}\text { Pasture in the vicinity of settle- } \\
\text { ments, } 43 \\
\text { Alpine meadows, } 45 \\
\text { Sheep alps, } 49 \\
\text { Favourable to pasturing, } 46 \\
\text { Stony alpine pasture, } 48 \\
\text { Grass and herb vegetation, } 65\end{array}$ & $\begin{array}{l}87303 \\
32316 \\
51124 \\
368691 \\
46024 \\
182384\end{array}$ & $\begin{array}{l}\text { Used for grazing, use not year- } \\
\text { round, not machine accessible }\end{array}$ \\
\hline $\begin{array}{l}\text { Intensively } \\
\text { used open land }\end{array}$ & 837128 & $\begin{array}{l}\text { Arable land, } 41 \\
\text { Natural meadows, } 42\end{array}$ & $\begin{array}{l}547754 \\
289374\end{array}$ & $\begin{array}{l}\text { Year-round use, in the vicinity } \\
\text { of settlements, Mown }\end{array}$ \\
\hline Other & 125186 & $1-40,44,47,61-64,66-72$ & 125186 & \\
\hline
\end{tabular}

Numbers in column 3 represent the official ASCH classes of the nomenclature 2004 (Humbel et al., 2010). The aggregation in Rutherford et al. (2008) was adapted to the new nomenclature. 


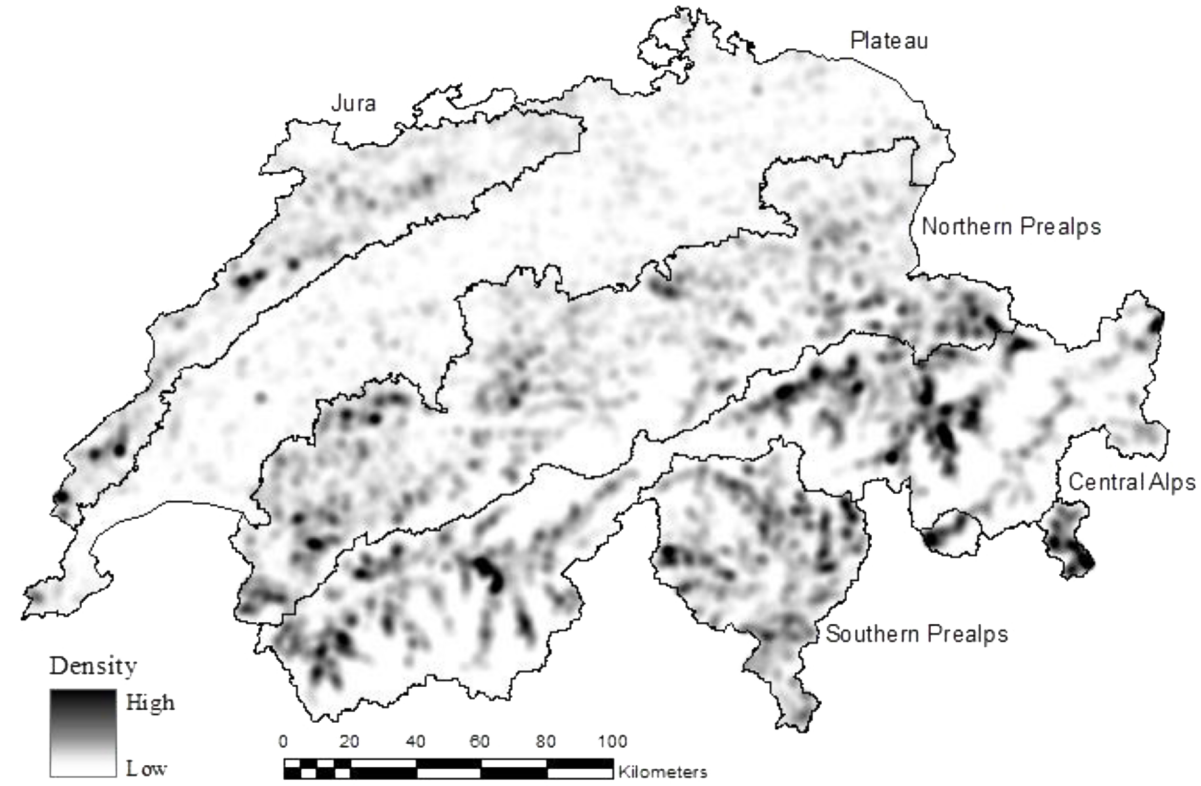

Figure A1. Spatial pattern of forest expansion. The pattern illustrates the density of forest expansion in Switzerland. The density was calculated including the area of all five transitions we used for calculating RF (see Sect. 2.3) and a kernel-density function in ArcGis 10.1 (ESRI). 

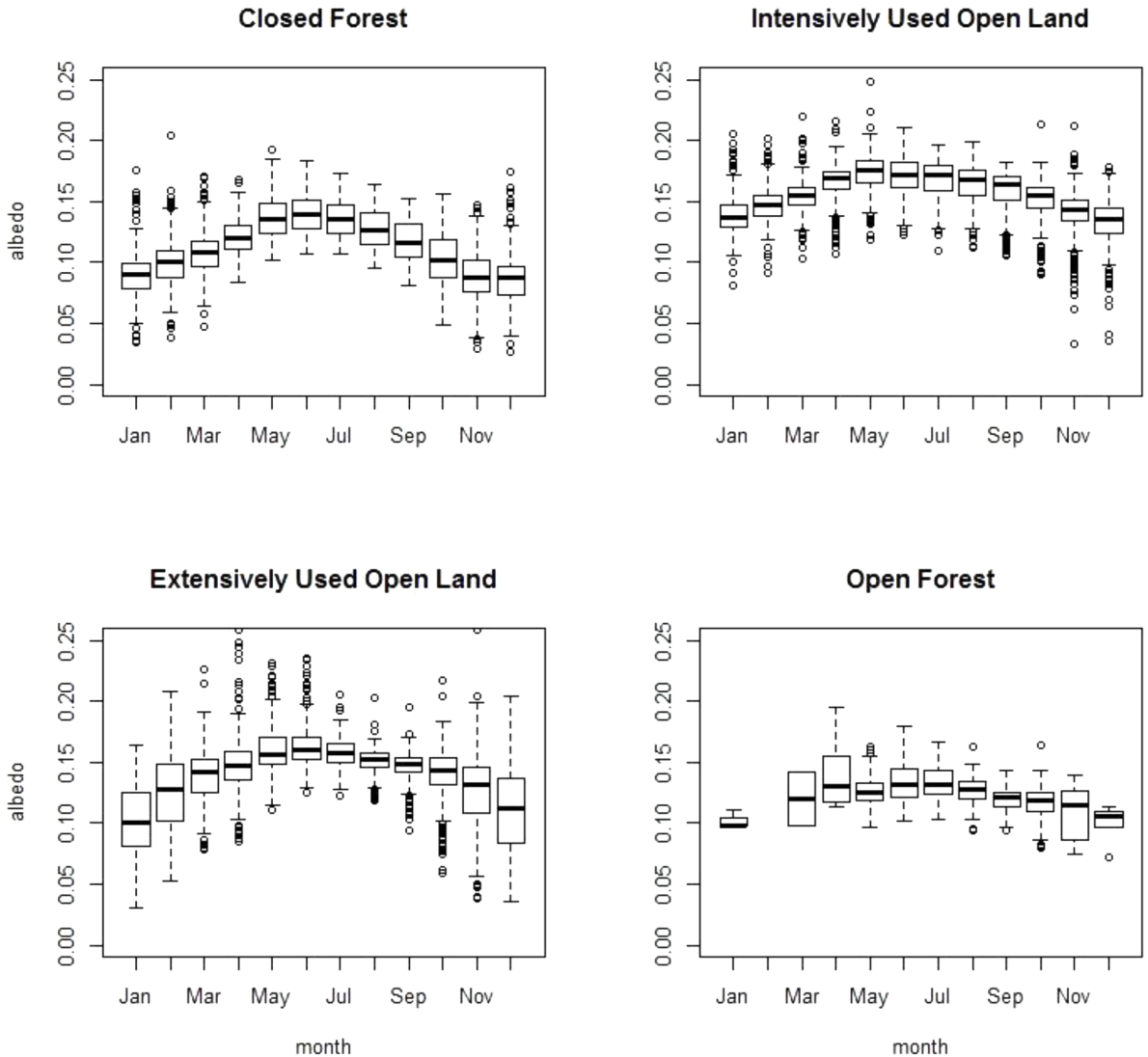

Figure A2. Seasonal variation of albedo values of the four snow-free LULC classes: closed forest, intensively used open land, extensively used open land and open forest (only full BRDF inversion albedo values). 

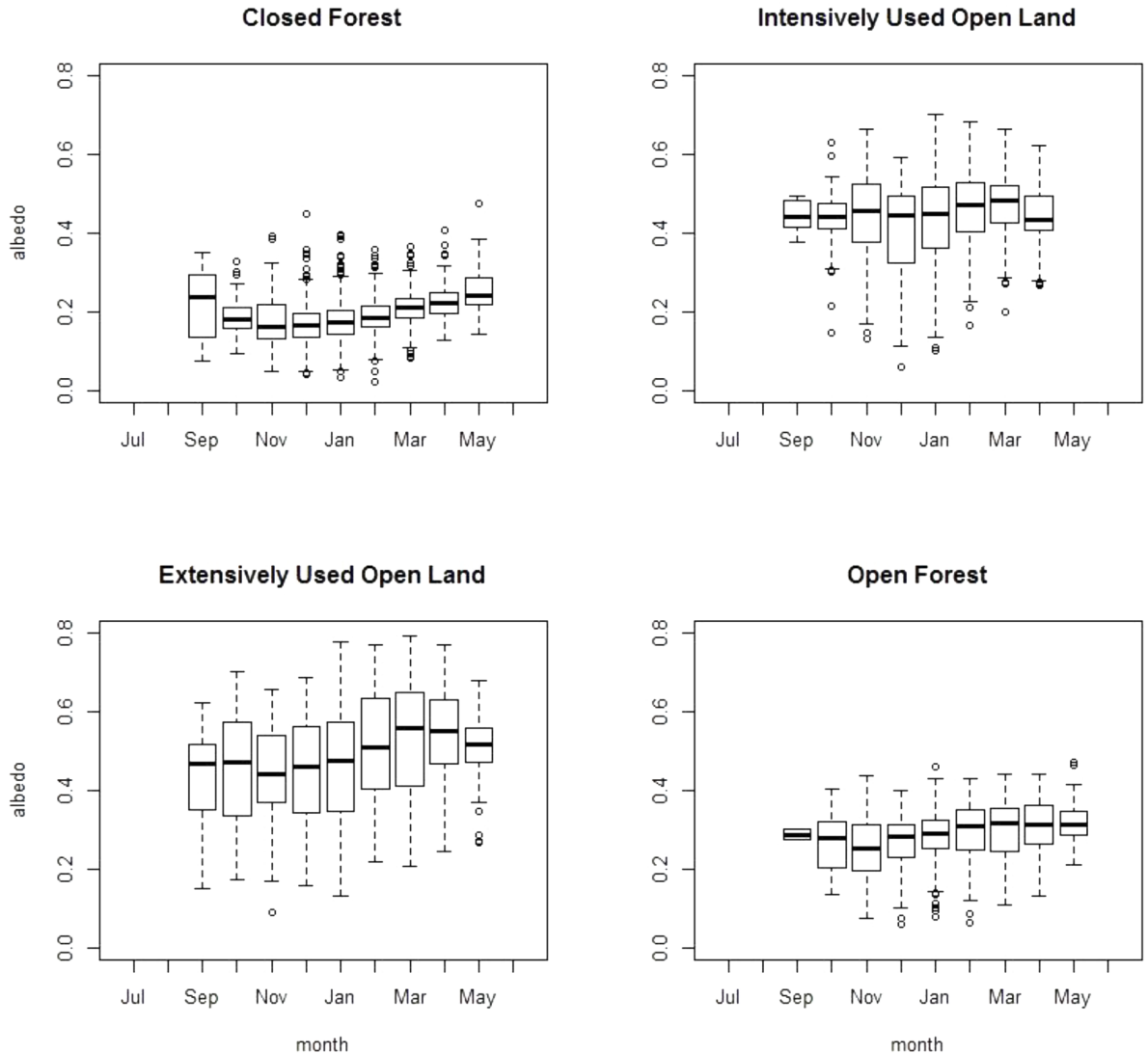

Figure A3. Seasonal variation of the albedo values of the four snow-covered LULC classes: closed forest, intensively used open land, extensively used open land and open forest (full BRDF albedo values and magnitude inversion albedo values for open forest). 
Acknowledgements. This work was part of the Swiss research programme "Forests and Climate change" and supported by the Swiss Federal Office for Environment (BAFU) and the Federal Institute for Forest, Snow and Landscape Research (WSL). We acknowledge the financial support by the NRP 68 programme of the Swiss National Science foundation and are grateful to Fortunat Joos, Stefan Wunderle, Janine Bolliger, Tobias Jonas, Henning Löwe and Michaela Teich for helpful discussions and Silvia Dingwall for language revision.

Edited by: C. A. Williams

\section{References}

Alewell, C. and Bebi, P.: Forest Development in the European Alps and Potential Consequences on Hydrological Regime, Forest Manage. Water Cy., 212, 111-126, 2011.

Arora, V. K. and Montenegro, A.: Small temperature benefits provided by realistic afforestation efforts, Nat. Geosci., 4, 514-518, 2011.

Bala, G., Caldeira, K., Wickett, M., Phillips, T. J., Lobell, D. B., Delire, C., and Mirin, A.: Combined climate and carbon-cycle effects of large-scale deforestation (vol. 104, p. 6550, 2007), Proc. Nat. Acad. Sci. USA, 104, 9911-9911, 2007.

Barnes, C. A. and Roy, D. P.: Radiative forcing over the conterminous United States due to contemporary land cover land use change and sensitivity to snow and interannual albedo variability, J. Geophys. Res.-Biogeosci., 115, 2010.

Bathiany, S., Claussen, M., Brovkin, V., Raddatz, T., and Gayler, V.: Combined biogeophysical and biogeochemical effects of largescale forest cover changes in the MPI earth system model, Biogeosciences, 7, 1383-1399, doi:10.5194/bg-7-1383-2010, 2010.

Baur, P.: Forest Expansion in the Swiss Alps: A quantitative analysis of bio-physical and socio-economic causes with an emphasis on structural changes in agriculture, Birmensdorf/Switzerland, 2006.

Bebi, P., Teich, M., Hagedorn, F., Zurbriggen, N., Brunner, S. H., and Grêt-Regamey, A.: Veränderung von Wald und Waldleistungen in der Landschaft Davos im Zuge des Klimawandels, Schweizerische Zeitschrift für Forstwesen, 493-501, 2012.

Bernier, P. Y., Desjardins, R. L., Karimi-Zindashty, Y., Worth, D., Beaudoin, A., Luo, Y., and Wang, S.: Boreal lichen woodlands: A possible negative feedback to climate change in eastern North America, Agr. Forest Meteorol., 151, 521-528, 2011.

Betts, R. A.: Offset of the potential carbon sink from boreal forestation by decreases in surface albedo, Nature, 408, 187-190, 2000.

Betts, R. A.: Climate Science Afforestation cools more or less, Nat. Geosci., 4, 504-505, 2011.

Beyer, H. G., Costanzo, C., and Heinemann, D.: Modifications of the Heliosat procedure for irradiance estimates from satellite images, Solar En., 56, 207-212, 1996.

Bloetzer, G.: Walderhaltungspolitik - Entwicklung und Urteil der Fachleute, in: Bundesamt für Umwelt, Wald und Landschaft (BUWAL), 2004.

Bolliger, J., Hagedorn, F., Leifeld, J., Bohl, J., Zimmermann, S., Soliva, R., and Kienast, F.: Effects of land-use change on carbon stocks in Switzerland, Ecosystems, 11, 895-907, 2008.
Bonan, G. B.: Forests and climate change: Forcings, feedbacks, and the climate benefits of forests, Science, 320, 1444-1449, 2008.

Brändli, U.-B.: Schweizerisches Landesforstinventar, Ergebnisse der dritten Erhebung 2004-2006, Results of the third Swiss national forest inventory 2004-2006, Birmensdorf, Eidgenössische Forschungsanstalt für Wald, Schnee und Landschaft WSL, Bern, Bundesamt für Umwelt, BAFU, p. 312, 2010.

Bright, R. M. and Kvalevåg, M. M.: Technical Note: Evaluating a simple parameterization of radiative shortwave forcing from surface albedo change, Atmos. Chem. Phys., 13, 11169-11174, doi:10.5194/acp-13-11169-2013, 2013.

Bürgi, M. and Schuler, A.: Driving forces of forest management-an analysis of regeneration practices in the forests of the Swiss Central Plateau during the 19th and 20th century, Forest Ecol. Manage., 176, 173-183, 2003.

Cano, D., Monget, J. M., Albuisson, M., Guillard, H., Regas, N., and Wald, L.: A Method For The Determination Of The Global Solar-Radiation From Meteorological Satellite Data, Solar En., 37, 31-39, 1986.

Cherubini, F., Peters, G. P., Berntsen, T., Stromman, A. H., and Hertwich, E.: $\mathrm{CO}(1)$ emissions from biomass combustion for bioenergy: atmospheric decay and contribution to global warming, Glob. Change Biol. Bioen., 3, 413-426, 2011.

Costa, M. H. and Foley, J. A.: Combined effects of deforestation and doubled atmospheric $\mathrm{CO}_{2}$ concentrations on the climate of Amazonia, J. Climate, 13, 18-34, 2000.

Davin, E. L. and De Noblet-Ducoudre, N.: Climatic Impact of Global-Scale Deforestation: Radiative versus Nonradiative Processes, J. Climate, 23, 97-112, 2010.

Davin, E. L., De Noblet-Ducoudre, N., and Friedlingstein, P.: Impact of land cover change on surface climate: Relevance of the radiative forcing concept, Geophys. Res. Lett., 34, 2007.

De Wit, H. A., Bryn, A., Hofgaard, A., Karstensen, J., Kvalevåg, M. M., and Peters, G. P.: Climate warming feedback from mountain birch forest expansion: reduced albedo dominates carbon uptake, Glob. Change Biol., 20, 2344-2355, 2014.

Durr, B., Zelenka, A., Muller, R., and Philipona, R.: Verification of CM-SAF and MeteoSwiss satellite based retrievals of surface shortwave irradiance over the Alpine region, Internat. J. Remote Sens., 31, 4179-4198, 2010.

Eckmeier, E., Egli, M., Schmidt, M. W. I., Schlumpf, N., Notzli, M., Minikus-Stary, N., and Hagedorn, F.: Preservation of firederived carbon compounds and sorptive stabilisation promote the accumulation of organic matter in black soils of the Southern Alps, Geoderma, 159, 147-155, 2010.

Forster, P., Ramaswamy, V., Artaxo, P., Berntsen, T., Betts, R., Fahey, D. W., Haywood, J., Lean, J., Lowe, D. C., Myhre, G., Nganga, J., Prinn, R., Raga, G., Schulz, M., and Dürr, R. V. D. E.: Changes in Atmospheric Constituents and in Radiative Forcing, in: Climate Change 2007: The Physical Science Basis, edited by: Solomon, S., Qin, D., Manning, M., Chen, Z., Marquis, M., Averyt, K. B., Tignor, M., and Miller, H. L., Contribution of Working Group I to the Fourth Assessment Report of the Intergovernmental Panel on Climate Change, Cambridge University Press, Cambridge, United Kingdom and New York, NY, USA, 2007.

$\mathrm{Fu}$, Q. and Liou, K. N.: Fu-Liou Cloud/Aerosol Forcing Page , NASA, available at: http://snowdog.larc.nasa.gov/cgi-bin/rose/ flp200503/flp200503.cgi, 2005. 
Gehrig-Fasel, J., Guisan, A., and Zimmermann, N. E.: Tree line shifts in the Swiss Alps: Climate change or land abandonment?, J. Vegetat. Sci., 18, 571-582, 2007.

Gibbard, S., Caldeira, K., Bala, G., Phillips, T. J., and Wickett, M.: Climate effects of global land cover change, Geophys. Res. Lett., 32, 2005.

Gimmi, U., Wolf, A., BÜRgi, M., Scherstjanoi, M., and Bugmann, H.: Quantifying disturbance effects on vegetation carbon pools in mountain forests based on historical data, Reg. Environ. Change, 9, 121-130, 2009.

Govindasamy, B., Duffy, P. B., and Caldeira, K.: Land use Changes and Northern Hemisphere Cooling, Geophys. Res. Lett., 28, 291-294, 2001.

Gret-Regamey, A., Brunner, S. H., Altwegg, J., Christen, M., and Bebi, P.: Integrating Expert Knowledge into Mapping Ecosystem Services Trade-offs for Sustainable Forest Management, Ecol. Soc., 18, 2013.

Gutersohn, H.: Naturräumliche Gliederung, Atlas der Schweiz, 1973.

Hagedorn, F., Moerl, A., Walthert, L., and Zimmermann, S.: Kohlenstoff in schweizer waldböden - bei Klima erwärmung eine potenzielle $\mathrm{CO}_{2}$-Quelle, Schweizerische Zeitschrift für Forstwesen, 161, 530-535, 2010.

Hagedorn, F., Shiyatov, S. G., Mazepa, V. S., Devi, N. M., Grigor'Ev, A. A., Bartish, A. A., Fomin, V. V., Kapralov, D. S., Terent'Ev, M., Bugman, H., Rigling, A., and Moiseev, P. A.: Treeline advances along the Urals mountain range - driven by improved winter conditions?, Glob. Change Biol., n/a-n/a, 20, 3530-3543, 2014.

Hammer, A., Heinemann, D., Hoyer, C., Kuhlemann, R., Lorenz, E., Muller, R., and Beyer, H. G.: Solar energy assessment using remote sensing technologies, Remote Sens. Environ., 86, 423432, 2003

Heldstab, J., Sommerhalder, M., and Rhim, B.: Switzerland's Greenhouse Gas Inventory 1990-2010, Bern: Federal Office for the Environment FOEN, 2012.

Hiltbrunner, D., Zimmermann, S., Karbin, S., Hagedorn, F., and Niklaus, P. A.: Increasing soil methane sink along a 120-year afforestation chronosequence is driven by soil moisture, Glob. Change Biol., 18, 3664-3671, 2012.

Hüsler, F., Jonas, T., Wunderle, S., and Albrecht, S.: Validation of a modified snow cover retrieval from historical 1-km AVHRR data over the European Alps, J. Geophys. Res., 121, 497-515, 2012.

Humbel, R., Beyeler, A., Burkhalter, J., Sager, J., and Zaugg, H.-U.: Arealstatistik nach Nomenklatur 2004 - Standard NOAS04, available at: http://www.bfs.admin.ch/bfs/portal/de/ index/dienstleistungen/geostat/datenbeschreibung/arealstatistik_ noas04.html, last access: 17 April 2010, 2010.

Hüsler, F., Jonas, T., Wunderle, S., and Albrecht, S.: Validation of a modified snow cover retrieval algorithm from historical 1-km AVHRR data over the European Alps, Remote Sens. Environ., 121, 497-515, 2012.

IPCC: Third Assessment Report - Appendix II, SRES Tables, 2001. IPCC: Good Practice Guidance for Land Use, Land-Use Change and Forestry (IPCC GPG LULUCF), 2003.

Joos, F., Roth, R., Fuglestvedt, J. S., Peters, G. P., Enting, I. G., Von Bloh, W., Brovkin, V., Burke, E. J., Eby, M., Edwards, N. R., Friedrich, T., Frolicher, T. L., Halloran, P. R., Holden, P. B., Jones, C., Kleinen, T., Mackenzie, F. T., Matsumoto, K.,
Meinshausen, M., Plattner, G. K., Reisinger, A., Segschneider, J., Shaffer, G., Steinacher, M., Strassmann, K., Tanaka, K., Timmermann, A., and Weaver, A. J.: Carbon dioxide and climate impulse response functions for the computation of greenhouse gas metrics: a multi-model analysis, Atmos. Chem. Phys., 13, 2793 2825, 2013.

Kaufmann, E.: Estimation of standing timber, growth and cut, in: Swiss National Forest Inventory: Methods and Models of the Second Assessment, edited by: Brassel, P. and Lischke, H., Swiss Federal Research Institute WSL, Birmensdorf, 162-196, 2001.

Kirschbaum, M. U. F., Whitehead, D., Dean, S. M., Beets, P. N., Shepherd, J. D., and Ausseil, A. G. E.: Implications of albedo changes following afforestation on the benefits of forests as carbon sinks, Biogeosciences, 8, 3687-3696, 2011.

Körner, C.: Alpine Treelines, Functional Ecology of the Global High Elevation Tree Limits, Basel, Springer, 2012.

Kozak, J.: Forest cover change in the Western Carpathians in the past 180 years - A case study in the Orawa Region in Poland, Mount. Res. Develop., 23, 369-375, 2003.

Kvalevag, M. M., Myhre, G., Bonan, G., and Levis, S.: Anthropogenic land cover changes in a GCM with surface albedo changes based on MODIS data, Internat. J. Climatol., 30, 2105 2117, 2010.

Laiolo, P., Dondero, F., Ciliento, E., and Rolando, A.: Consequences of pastoral abandonment for the structure and diversity of the alpine avifauna, J. Appl. Ecol., 41, 294-304, 2004.

Lee, X., Goulden, M. L., Hollinger, D. Y., Barr, A., Black, T. A., Bohrer, G., Bracho, R., Drake, B., Goldstein, A., Gu, L. H., Katul, G., Kolb, T., Law, B. E., Margolis, H., Meyers, T., Monson, R., Munger, W., Oren, R., Kyaw, T. P. U., Richardson, A. D., Schmid, H. P., Staebler, R., Wofsy, S., and Zhao, L.: Observed increase in local cooling effect of deforestation at higher latitudes, Nature, 479, 384-387, 2011.

Leifeld, J., Bassin, S., and Fuhrer, J.: Carbon stocks in Swiss agricultural soils predicted by land-use, soil characteristics, and altitude, Agr. Ecosyst. Environ., 105, 255-266, 2005.

Liu, J. C., Schaaf, C., Strahler, A., Jiao, Z. T., Shuai, Y. M., Zhang, Q. L., Roman, M., Augustine, J. A., and Dutton, E. G.: Validation of Moderate Resolution Imaging Spectroradiometer (MODIS) albedo retrieval algorithm: Dependence of albedo on solar zenith angle, J. Geophys. Res.-Atmosph., 114, 2009.

Luyssaert, S., Jammet, M., Stoy, P. C., Estel, S., Pongratz, J., Ceschia, E., Churkina, G., Don, A., Erb, K., Ferlicoq, M., Gielen, B., Grunwald, T., Houghton, R. A., Klumpp, K., Knohl, A., Kolb, T., Kuemmerle, T., Laurila, T., Lohila, A., Loustau, D., Mcgrath, M. J., Meyfroidt, P., Moors, E. J., Naudts, K., Novick, K., Otto, J., Pilegaard, K., Pio, C. A., Rambal, S., Rebmann, C., Ryder, J., Suyker, A. E., Varlagin, A., Wattenbach, M., and Dolman, A. J., Land management and land-cover change have impacts of similar magnitude on surface temperature, Nat. Clim. Change, 4, 389-393, 2014.

Macdonald, D., Crabtree, J. R., Wiesinger, G., Dax, T., Stamou, N., Fleury, P., Lazpita, J. G., and Gibon, A.: Agricultural abandonment in mountain areas of Europe: Environmental consequences and policy response, J. Environ. Manage., 59, 47-69, 2000.

Meteoswiss, F. O. O. M. A. C.: Available: http://www. meteoschweiz.admin.ch/web/en/services/data_portal/grided_ datasets/radiation.html, last access: 28 February 2012. 
Montenegro, A., Eby, M., Mu, Q. Z., Mulligan, M., Weaver, A. J., Wiebe, E. C., and Zhao, M. S.: The net carbon drawdown of small scale afforestation from satellite observations, Glob. Planet. Change, 69, 195-204, 2009.

Myhre, G., Highwood, E. J., Shine, K. P., and Stordal, F.: New estimates of radiative forcing due to well mixed greenhouse gases, Geophys. Res. Lett., 25, 2715-2718, 1998.

Myhre, G., Shindell, D., BrÉOn, F.-M., Collins, W., Fuglestvedt, J., Huang, J., Koch, D., Lamarque, J.-F., Lee, D., Mendoza, B., Nakajima, T., Robock, A., Stephens, G., Takemura, T., and Zhang, H.: Climate Change 2013: The Physical Science Basis. Contribution of Working Group I to the Fifth Assessment Report of the Intergovernmental Panel on Climate Change, Anthrop. Nat. Radiat. Forc., 2013.

Nussbaum, M., Papritz, A., Baltensweiler, A., and Walthert, L.: Organic Carbon Stocks of Swiss Forest Soils, Final Report.: Institute of Terrestrial Ecosystems, ETH Zürich and Swiss Federal Institute for Forest, Snow and Landscape Research (WSL), Zürich and Birmensdorf, 2012.

O’Halloran, T. L., Law, B. E., Goulden, M. L., Wang, Z. S., Barr, J. G., Schaaf, C., Brown, M., Fuentes, J. D., Gockede, M., Black, A., and Engel, V.: Radiative forcing of natural forest disturbances, Glob. Change Biol., 18, 555-565, 2012.

Perruchoud, D., Kienast, F., Kaufmann, E., and Braker, O. U.: 20th century carbon budget of forest soils in the Alps, Ecosystems, 2, 320-337, 1999.

Pitman, A. J., Avila, F. B., Abramowitz, G., Wang, Y. P., Phipps, S. J., and De Noblet-Ducoudre, N.: Importance of background climate in determining impact of land-cover change on regional climate, Nat. Clim. Change, 1, 472-475, 2011.

Poeplau, C., Don, A., Vesterdal, L., Leifeld, J., Van Wesemael, B., Schumacher, J., and Gensior, A.: Temporal dynamics of soil organic carbon after land-use change in the temperate zone - carbon response functions as a model approach, Glob. Change Biol., 17, 2415-2427, 2011.

Pujol, G., Iooss, B., and Janon, A.: Sensitivity Analysis, Version 1.6-1, 2012.

Ramankutty, N., Heller, E., and Rhemtulla, J.: Prevailing Myths About Agricultural Abandonment and Forest Regrowth in the United States, Ann. Assoc. Am. Geogr., 100, 502-512, 2010.

Roesch, A., Wild, M., Pinker, R., and Ohmura, A.: Comparison of spectral surface albedos and their impact on the general circulation model simulated surface climate, J. Geophys. Res., 107, ACL13-1-ACL13-ACL13-18ACL13-ACL13-18, 2002.

Rutherford, G. N., Bebi, P., Edwards, P. J., and Zimmermann, N. E.: Assessing land-use statistics to model land cover change in a mountainous landscape in the European Alps, Ecol. Modell., 212, 460-471, 2008.

Saltelli, A., Tarantola, S., and Chan, K. P. S.: A quantitative modelindependent method for global sensitivity analysis of model output, Technometrics, 41, 39-56, 1999.
Schaaf, C.: MODIS BRDF/Albedo Product (MCD43) User's Guide , available at: http://www-modis.bu.edu/brdf/userguide/ intro.html (last access: 30 March 2012), 2010.

Schaeffer, M., Eickhout, B., Hoogwijk, M., Strengers, B., Van Vuuren, D., Leemans, R., and Opsteegh, T.: $\mathrm{CO}_{2}$ and albedo climate impacts of extratropical carbon and biomass plantations, Global Biogeochem. Cy., 20, 2006.

Schneeberger, N., BÜRgi, M., and Kienast, P. D. F.: Rates of landscape change at the northern fringe of the Swiss Alps: Historical and recent tendencies, Landscape Urban Plann., 80, 127-136, 2007.

Schwaiger, H. P., and Bird, D. N.: Integration of albedo effects caused by land use change into the climate balance: Should we still account in greenhouse gas units?, Forest Ecol. Manage., 260, 278-286, 2010.

Siegenthaler, U. and Oeschger, H.: predicting future atmospheric carbon-dioxide levels, Science, 199, 388-395, 1978.

Sjörgersten-Turner, S., Alewell, C., CÉCillon, L., Hagedorn, F., Jandl, R., Leifeld, J., Vegard, M., Schindlbacher, A., SebastiÁ, M. T., and Van Miegroet, H.: Mountain soils in a changing climate - vulnerability of carbon stocks and ecosystem feedbacks, in: Soil Carbon in Sensitive European Ecosystems, edited by: Jandl, R., Mirco, R., and Mats, O., Wiley-Blackwell, 118-139, 2011.

Spracklen, D. V., Bonn, B., and Carslaw, K. S.: Boreal forests, aerosols and the impacts on clouds and climate, Philosophical Transactions of the Royal Society a-Mathematical Physical and Engineering Sciences, 366, 4613-4626, 2008.

Strahler, A. H., Lucht, W., Schaaf, C. B., Tsang, T., Gao, F., Li, X., Muller, J.-P., Lewis, P., and Barnsley, M. J.: MODIS BRDF/Albedo Product: Algorithm Theoretical Basis Document Version 5.0, 1999.

UNFCC: Decision 11/CP.7: Land Use, Land-use Change and Forestry, in: Generic biomass functions for Norway spruce in Central Europe - a meta-analysis approach toward prediction and uncertainty estimation., edited by: Change, U. N. F. C. O. C., Wirth, C., Schumacher, J., and Schulze, E. D., Tree Physiology, 24, 121-139, 2001.

Wohlgemuth, T.: Biogeographical Regionalization of Switzerland Based on Floristic Data: How Many Species are Needed?, Biodivers. Lett., 1996.

Wutzler, T., Wirth, C., and Schumacher, J.: Generic biomass functions for Common beech (Fagus sylvatica) in Central Europe: predictions and components of uncertainty, Can. J. Forest Res., 38, 1661-1675, 2008.

Zhou, L., Dickinson, R. E., Tian, Y., Zeng, X., Dai, Y., Yang, Z. L., Schaaf, C. B., Gao, F., Jin, Y., Strahler, A., Myneni, R. B., Yu, H., Wu, W., and Shaikh, M.: Comparison of seasonal and spatial variations of albedos from Moderate-Resolution Imaging Spectroradiometer (MODIS) and Common Land Model, J. Geophys. Res.-Atmos., 108, 2003. 